\title{
RESEARCH
}

Open Access

\section{Non-timber forest products and their contribution to healthcare and livelihood security among the Karbi tribe in Northeast India}

Puranjoy Mipun ${ }^{1 *} \mathbb{D}$, Nazir Ahmad Bhat ${ }^{1}$, Dipankar Borah² and Yogendra Kumar ${ }^{1}$

\begin{abstract}
Introduction: Non-timber forest products (NTFPs) have been an essential source for food, medicine, and handicraft products among the indigenous populations living in forested areas for millennia. Scientific research on the restoration of the importance of NTFPs and their value addition could potentially guide the development of new nutraceutical products in the future. The present study aims to investigate the diversity of non-timber forest products of the Karbi Anglong District of Assam in Northeast India.

Methods: Multistage sampling technique was used for the study. A total of 70 respondents from 7 randomly selected villages were interviewed with a well-developed semi-structured questionnaire to explore the utilisation of NTFPs. Data analysis was done using four quantitative indices: (a) use report (UR), (b) use value (UV), (c) informant consensus factor (ICF), and (d) fidelity level (FL).

Results: A total of 138 plant species belonging to 59 families distributed in 110 genera were recorded and identified as NTFPs of 1 type or the other. These include $42 \%$ having ethnomedicinal use, 33\% as edible forest products, $15 \%$ as household building materials and utensils, $6 \%$ as spices and condiments, and $4 \%$ as herbal dyes. Among the medicinal plant species, Abroma augustum (L.) L. f., Amaranthus spinosus L, and Geophila repens (L.) I. M. Johnst. showed the highest ICF and FL.

Conclusions: The present study confirms that NTFPs have played an essential role in the healthcare and livelihood of the indigenous people of the Karbi tribe throughout their generations and continue to do so. Also, the species with high value for both ICF and FL could be used for the development of new, cheap, effective, and eco-friendly herbal formulations for healthcare management leading to economic and social benefits to the indigenous tribe. However, anthropogenic pressure and overexploitation of NTFPs may lead to the loss of this precious natural resource from this area.
\end{abstract}

Keywords: East Karbi Anglong, Ethnobotany, Forest income, NTFPs, Wildlife sanctuary, Quantitative study, Medicinal plants

\footnotetext{
* Correspondence: mipunpuranjoy@gmail.com

${ }^{1}$ Centre for Advanced Studies in Botany, North-Eastern Hill University,

Shillong, Meghalaya 793022, India

Full list of author information is available at the end of the article
} 


\section{Introduction}

All biological products, other than timber or products of animal origin, that are harvested from forests and manipulated for human and animal use, are described as non-timber forest products (NTFPs) (Ros-Tonen et al. 1995). NTFPs play a vital role in supporting livelihood security, development, and poverty reduction, especially for the rural communities living around forest areas (Cocks and Wiersum 2003; Cocksedge 2006; Endamana et al. 2016). It also has substantial cultural significance and value for various ethnic groups around the world. However, the importance of NTFPs tends to be underestimated as they are not traded through organised markets and do not appear in national economic statistics even though millions of forest dwellers harvest large quantities of NTFPs for both subsistence and commercial use, either regularly or as an emergency (Shaanker et al. 2004).

In India, $90 \%$ of the plants supplied to the international market are from the wild stock (Mishra et al. 2009). It is therefore essential to develop a systematic and rigorous data collection system in all the developing countries for better utilisation of NTFPs. Moreover, if the government and stakeholders take the initiative to
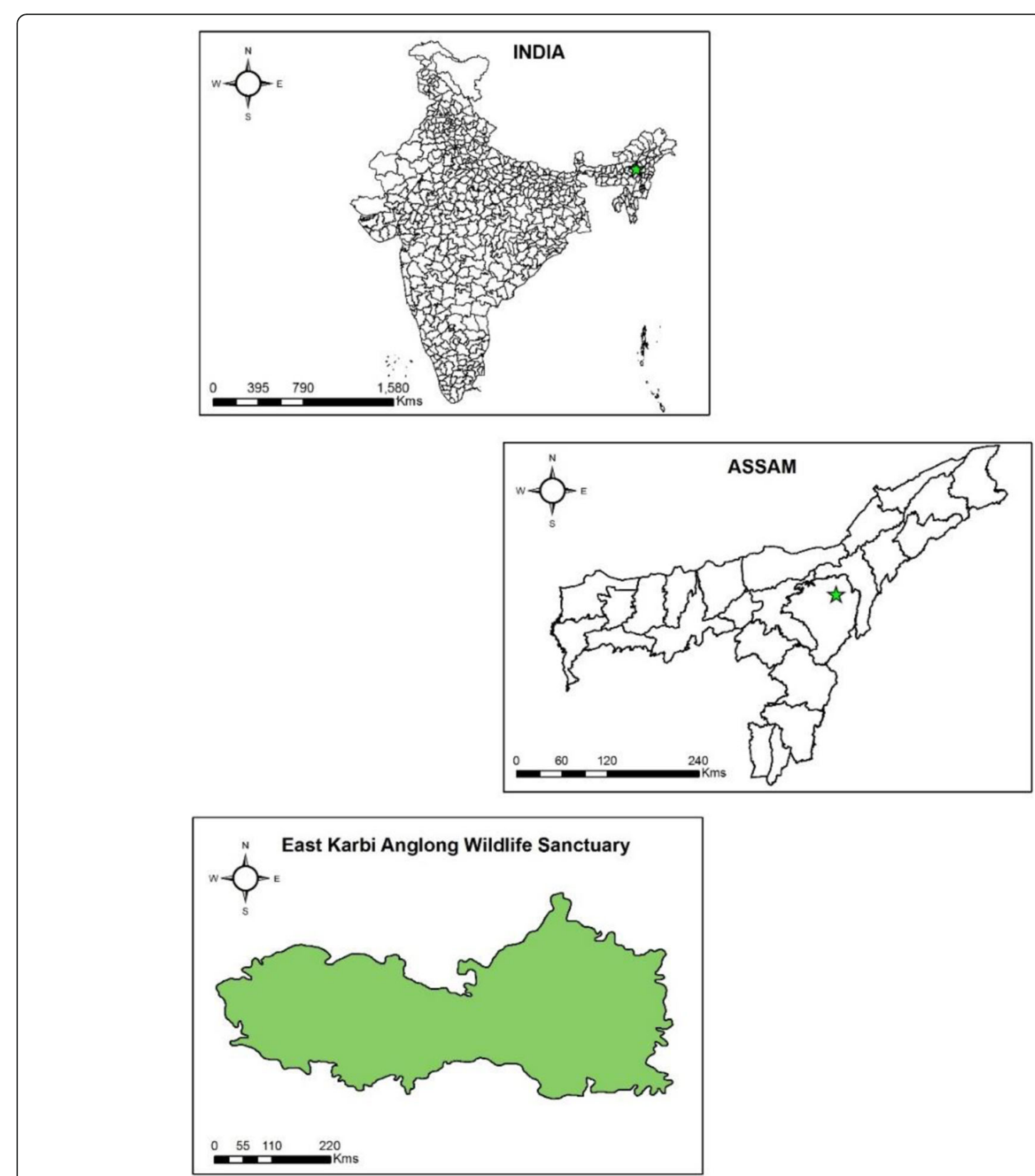

Fig. 1 Map of East Karbi Anglong Wildlife Sanctuary, Assam, indicating selected area for study 
Table 1 Demographic characteristics of informants for NTFPs surveys in East Karbi Anglong Wildlife Sanctuary

\begin{tabular}{|c|c|c|c|c|c|c|c|}
\hline Villages & Borpung & Tarapung & Noralangso & Phanglangso & Langtuk hanse & Langpratlangso & Kanduwa bosti \\
\hline Male & 7 & 6 & 7 & 8 & 7 & 8 & 6 \\
\hline Female & 3 & 4 & 3 & 2 & 3 & 2 & 4 \\
\hline Total households & 10 & 10 & 10 & 10 & 10 & 10 & 10 \\
\hline Total respondents & 10 & 10 & 10 & 10 & 10 & 10 & 10 \\
\hline
\end{tabular}

prioritise the sustainable use of NTFPs, the economic and social well-being of communities living in and around forest lands could be enhanced substantially (Agrawal et al. 2013). The increasing threat of largescale deforestation and degradation of the natural habitat poses a significant hazard to various forest resources, particularly NTFPs. Therefore, it is important to urgently develop appropriate management strategies and practical plans before these elements are lost forever (Pandey and Saini 2007).

Northeast India spreads over an area of $255,088 \mathrm{~km}^{2}$, constituting $7.7 \%$ of the total geographical area of the country. A large number of different indigenous communities in this region are traditionally dependent on forest products, especially on NTFPs, which play a significant role in the maintenance of subsistence and provision of food and medicine. It is estimated that 60 94\% of the tribal population in states like Arunachal Pradesh, Nagaland, Manipur, and Tripura are dependent on forest resources for various purposes (Dattagupta and Gupta 2016). Earlier studies of NTFPs in Assam are minimal in comparison to other Indian states (Sarma et al. 2016). One research has shown that forest dwellers of the Inner Line Reserve Forest of Cachar District in the Barak Valley region collect 67 plant species as
NTFPs of 40 families (Dattagupta et al. 2010, 2014). Another study on the commercial uses of forest products in Karbi Anglong District of Assam has shown that the forest remains the backbone of the economy for the people living in this area (Timunpi 2017).

Quantitative ethnobotany is the application of quantitative techniques to direct analysis of contemporary plant use data (Phillips and Gentry 1993). This approach aims to describe the variables quantitatively and analyse the observed patterns to test different hypotheses about the relationship between plant species and humans (Höft et al. 1999; ReyesGarcía et al. 2006). One advantage of using this method, in addition to the systematic quantification, is that it helps to produce quality information, which in turn supplies substantially to resource conservation and development (Hussain et al. 2018). Quantitative ethnobotanical indices have so far been able to measure the various uses of plants whether as food, veterinary medicine, remedies for human disease, or economic value (Pieroni 2001; Upadhyay et al. 2011; Kim and Song 2013; Reyes-García et al. 2006). Although a few relevant ethnobotanical studies among the Karbi tribe have been conducted (Sankar and Chowdhury 2000; Kar and Borthakur 2008; Teron and Borthakur 2012; Teron and Borthakur 2013; Phongchopi et al. 2014; Terangpi et al. 2014; Teronpi et al. 2015; Singh 2017), none of

\section{Habits}

\section{0}

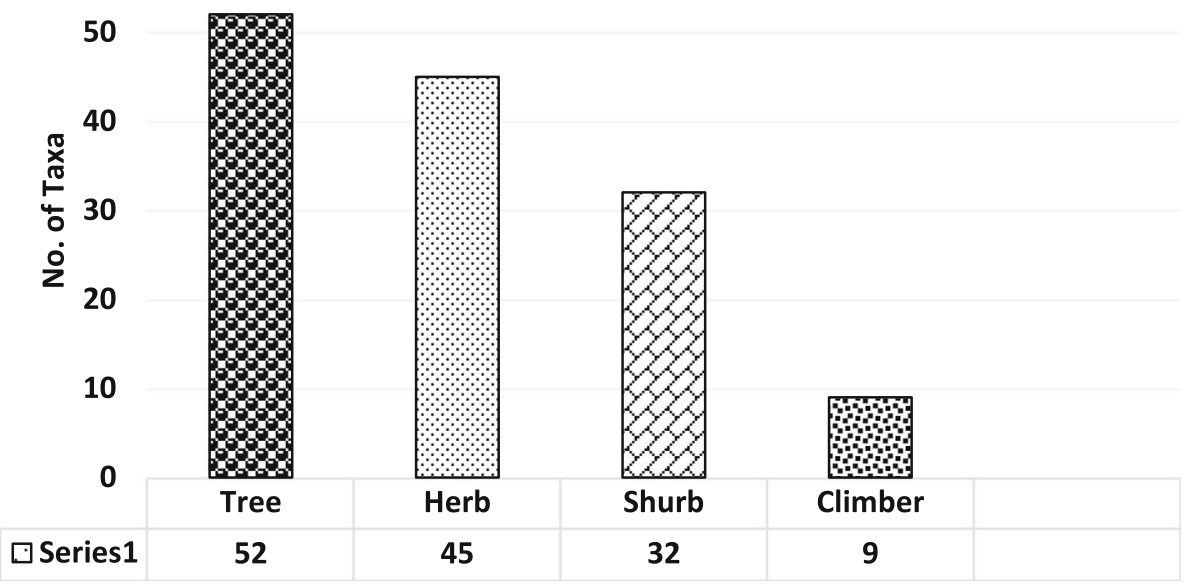

Fig. 2 Diversity of NTFPs as per habit 


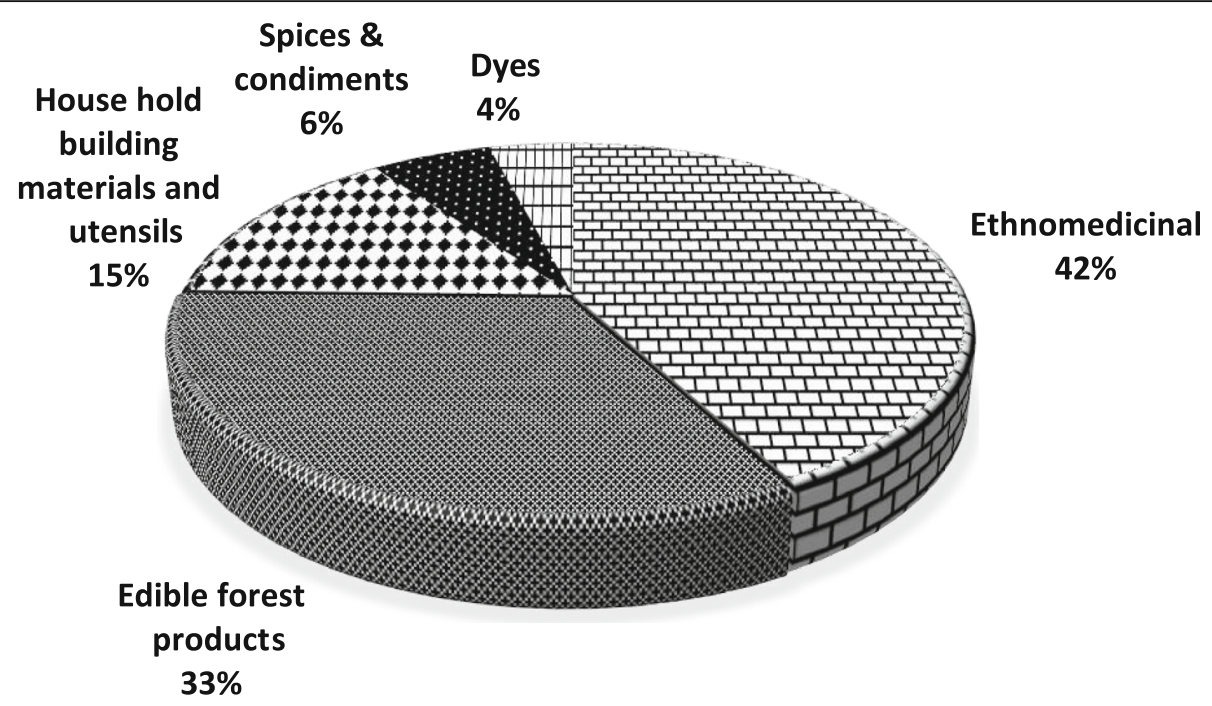

Fig. 3 Categories of non-timber forest products collected from East Karbi Anglong Wildlife Sanctuary

them have been able to document those studies using quantitative ethnobotanical techniques. Ethnobotanical studies using quantitative approach have a significant potential to enhance the indicative value of ethnobotanical studies and can enhance the factual information available for conservation and development of the existing resources.

Apart from some plant diversity studies carried out in Karbi Anglong District, no extensive study has been carried out to evaluate the exact wealth of the hilly terrains present in the area. This study explores NTFPs used by the indigenous Karbi community, evaluates different ethnobotanical indices, and examines the dependence of the forest dwellers on this existing resource in East Karbi Anglong Wildlife Sanctuary in the Karbi Anglong District of Assam.

\section{Methods}

\section{Study area}

The present study was carried out in East Karbi Anglong Wildlife Sanctuary of Karbi Anglong District of Assam, which is one of the primary forests of the state covering an area of $221.81 \mathrm{~km}^{2}$ (Fig. 1). It is situated between $24^{\circ}$ $33^{\prime} \mathrm{N}$ to $26^{\circ} 35^{\prime} \mathrm{N}$ latitude and $92^{\circ} 10^{\prime} \mathrm{E}$ to $93^{\circ} 50^{\prime} \mathrm{E}$ longitude and is $80-600 \mathrm{~m}$ asl. It is an essential component of the Karbi Anglong-Kaziranga landscape. The topography of the study site ranges from undulating hills to wide valleys and steep gorges with rivers and creeks, as well as annual and perennial streams. The wildlife sanctuary holds different forest types ranging from moist semievergreen, moist mixed deciduous to miscellaneous type with scattered pure or mixed patches of bamboos. Some of the prominent tree species found in the sanctuary are Hoong (Dipterocarpus macrocarpus), Mekai (Shorea assamica), Nahar (Mesua ferrea), Sia-nahar (Keyea assamica), Sissoo (Dalbergia sissoo), Khair (Acacia catechu), Helika (Terminalia chebula), etc. The soil is well-drained, sandy loamy to clayey loamy, and the climate is warm and humid with an annual rainfall of $1800 \mathrm{~mm}$. The average maximum temperature is around $30^{\circ} \mathrm{C}$ in August, and the minimum goes down to $6.5^{\circ} \mathrm{C}$ in winter.

\section{Participatory rural assessment}

The present field survey was carried out from 2015 to 2017, mainly in the villages surrounding the sanctuary.

Table 2 Details of villages surveyed in investigations of the NTFPs in East Karbi Anglong Wildlife Sanctuary

\begin{tabular}{llllll}
\hline SI. no. & Villages & Population & Latitude (N) (DMS) & Longitude (E) (DMS) & Altitude (m) \\
\hline 1 & Borpung & 2132 & $26^{\circ} 23^{\prime} 21.6564^{\prime \prime} \mathrm{N}$ & $93^{\circ} 28^{\prime} 17.8932^{\prime \prime} \mathrm{E}$ & 340 \\
2 & Tarapung & 1752 & $26^{\circ} 28^{\prime} 07.396^{\prime \prime} \mathrm{N}$ & $93^{\circ} 30^{\prime} 1.688^{\prime \prime} \mathrm{E}$ & 300 \\
3 & Noralangso & 960 & $26^{\circ} 27^{\prime} 25.088^{\prime \prime} \mathrm{N}$ & $93^{\circ} 27^{\prime} 56.627^{\prime \prime} \mathrm{E}$ & 344 \\
4 & Phanglangso & 1172 & $26^{\circ} 22^{\prime} 23.761^{\prime \prime} \mathrm{N}$ & $93^{\circ} 20^{\prime} 14.985^{\prime \prime} \mathrm{E}$ & 440 \\
5 & Langtuk hanse & 720 & $26^{\circ} 26^{\prime} 7.0476^{\prime \prime} \mathrm{N}$ & $93^{\circ} 27^{\prime} 49.6404^{\prime \prime} \mathrm{E}$ & 456 \\
6 & Langpratlangso & 1183 & $26^{\circ} 24^{\prime} 22.9^{\prime \prime} \mathrm{N}$ & $93^{\circ} 26^{\prime} 39.073^{\prime \prime} \mathrm{E}$ & 540 \\
7 & Kanduwa bosti & 1240 & $26^{\circ} 22^{\prime} 34.1868^{\prime \prime} \mathrm{N}$ & $93^{\circ} 21^{\prime} 22.1868^{\prime \prime} \mathrm{E}$ & 458 \\
\hline
\end{tabular}

Source: local headmen of respective villages 
Table 3 Enumeration of medicinal plant species used by the Karbi tribe in East Karbi Anglong Wildlife Sanctuary

\begin{tabular}{|c|c|c|c|c|c|c|}
\hline Botanical name & Local name & Habit & $\begin{array}{l}\text { Parts } \\
\text { used }\end{array}$ & Medicinal uses & $\begin{array}{l}\text { Used } \\
\text { type }\end{array}$ & Mode of application \\
\hline Abroma augustum (L.) L.f. (Malvaceae) & Korai & $\mathrm{S}$ & $\mathrm{R}$ & 1. Amenorrhea, dysmenorrhoea & $\mathrm{O}$ & 1. Decoction of root \\
\hline Abrus precatorius L. (Fabaceae) & Chuselok & C & $\mathrm{R}, \mathrm{L}$ & $\begin{array}{l}\text { 1. Malaria } \\
\text { 2. Fever, cold, cough }\end{array}$ & $\begin{array}{l}\mathrm{O} \\
\mathrm{O}\end{array}$ & $\begin{array}{l}\text { 1. Decoction of root } \\
\text { 2. Decoction of leaf }\end{array}$ \\
\hline Acacia pennata (L.) Willd. (Fabaceae) & Khemra & $\mathrm{T}$ & $B, L, R$ & $\begin{array}{l}\text { 1. Cut, wound, antidote against } \\
\text { insect bites } \\
\text { 2. Stomach ache, dyspepsia }\end{array}$ & $\begin{array}{l}\mathrm{T} \\
\mathrm{O}\end{array}$ & $\begin{array}{l}\text { 1. Paste of bark and leaf } \\
\text { 2. Decoction of root }\end{array}$ \\
\hline Aegle marmelos (L.) Correa (Rutaceae) & Thepli & T & $L, F$, & $\begin{array}{l}\text { 1. Stomach ache } \\
\text { 2. Dysentery, constipation, } \\
\text { haemorrhoids, cure weak health }\end{array}$ & $\begin{array}{l}\mathrm{O} \\
\mathrm{O}\end{array}$ & $\begin{array}{l}\text { 1. Mixture of leaf and fruits } \\
\text { with water } \\
\text { 2. Juice of fruits }\end{array}$ \\
\hline Alocasia macrorrhizos (L.) G.Don (Araceae) & Henchala & $\mathrm{H}$ & $\begin{array}{l}\mathrm{L}, \mathrm{St} \\
\mathrm{Cr}\end{array}$ & $\begin{array}{l}\text { 1. Antidote against insect bites } \\
\text { 2. Diarrhoea, stomach ache }\end{array}$ & $\begin{array}{l}\mathrm{T} \\
\mathrm{O}\end{array}$ & $\begin{array}{l}\text { 1. Paste of leaf and stem } \\
\text { 2. Corm decoction }\end{array}$ \\
\hline $\begin{array}{l}\text { Alpinia nigra (Gaertn.) Butt } \\
\text { (Zingiberaceae) }\end{array}$ & Tara & $\mathrm{H}$ & $\mathrm{Rh}$ & $\begin{array}{l}\text { 1. Stomach ache, sore throat } \\
\text { 2. Headache, lumbago }\end{array}$ & $\begin{array}{l}\mathrm{O} \\
\mathrm{T}\end{array}$ & $\begin{array}{l}\text { 1. Juice of rhizome } \\
\text { 2. Paste of rhizome }\end{array}$ \\
\hline $\begin{array}{l}\text { Alternanthera sessilis (L.) R. Br. Ex DC. } \\
\text { (Amaranthaceae) }\end{array}$ & Utokreng & $\mathrm{H}$ & Wp, & 1. Urinary disorder, haematuria & O & 1. Decoction of whole plant \\
\hline $\begin{array}{l}\text { Alternanthera philoxeroides (Mart.) Griseb. } \\
\text { (Amaranthaceae) }\end{array}$ & Utokreng & $\mathrm{H}$ & $L, W p$ & $\begin{array}{l}\text { 1. Skin allergies } \\
\text { 2. Urinary disorder }\end{array}$ & $\begin{array}{l}\mathrm{T} \\
\mathrm{O}\end{array}$ & $\begin{array}{l}\text { 1. Paste of fresh leaf } \\
\text { 2. Infusion of whole plant }\end{array}$ \\
\hline Amaranthus spinosus L. (Amaranthaceae) & Dido & $\mathrm{H}$ & Wp, L & $\begin{array}{l}\text { 1. Antidote against insects bite } \\
\text { 2. Nosebleed }\end{array}$ & $\begin{array}{l}\mathrm{T} \\
\mathrm{N}\end{array}$ & $\begin{array}{l}\text { 1. Juice of whole plant } \\
\text { 2. Juice of leaf }\end{array}$ \\
\hline $\begin{array}{l}\text { Amblovenatum opulentum J.P. Roux } \\
\text { (Thelypteridaceae) }\end{array}$ & Babkeso & S & Wp & 1. Ectoparasitic control in poultry & $\mathrm{T}$ & $\begin{array}{l}\text { 1. Whole plant is applied } \\
\text { directly }\end{array}$ \\
\hline Annona reticulata L. (Annonaceae) & $\begin{array}{l}\text { Longle } \\
\text { jangphong }\end{array}$ & $\mathrm{T}$ & $F, L$ & $\begin{array}{l}\text { 1. Diarrhoea, dysentery } \\
\text { 2. Helminthiasis }\end{array}$ & $\begin{array}{l}\mathrm{O} \\
\mathrm{O}\end{array}$ & $\begin{array}{l}\text { 1. Direct feeding of fruits } \\
\text { 2. Decoction of leaf }\end{array}$ \\
\hline Annona squamosa L. (Annonaceae) & $\begin{array}{l}\text { Longle } \\
\text { jangphong }\end{array}$ & $\mathrm{T}$ & $\mathrm{L}$ & 1. Ectoparasitic control in poultry & $\mathrm{T}$ & $\begin{array}{l}\text { 1. Whole plant is applied } \\
\text { directly }\end{array}$ \\
\hline Azadirachta indica A. Juss. (Meliaceae) & Neem & T & $L, R$ & $\begin{array}{l}\text { 1. Skin acne } \\
\text { 2. Fever } \\
\text { 3. Skin acne in cattle, ectoparasitic } \\
\text { control in cattle }\end{array}$ & $\begin{array}{l}\mathrm{T} \\
\mathrm{O} \\
\mathrm{T}\end{array}$ & $\begin{array}{l}\text { 1. Paste of leaf } \\
\text { 2. Decoction of root } \\
\text { 3. Paste of leaf, decoction of } \\
\text { root and leaf }\end{array}$ \\
\hline Baccaurea ramiflora Lour. (Phyllanthaceae) & Dampijuk & $\mathrm{T}$ & $\mathrm{F}$ & $\begin{array}{l}\text { 1. Scurvy } \\
\text { 2. Skin infection }\end{array}$ & $\begin{array}{l}\mathrm{O} \\
\mathrm{T}\end{array}$ & $\begin{array}{l}\text { 1. Direct consumption of fruits } \\
\text { 2. Juice of fruits }\end{array}$ \\
\hline Bauhinia racemosa Lam. (Fabaceae) & Ingku & $\mathrm{T}$ & $\mathrm{R}, \mathrm{Fl}$ & $\begin{array}{l}\text { 1. Stomach ache } \\
\text { 2. Cold, cough }\end{array}$ & $\begin{array}{l}\mathrm{O} \\
\mathrm{O}\end{array}$ & $\begin{array}{l}\text { 1. Decoction of root } \\
\text { 2. Decoction of flower }\end{array}$ \\
\hline Bauhinia variegata Linn. (Fabaceae) & Ingku-ke er & $\mathrm{T}$ & $\begin{array}{l}\mathrm{R}, \mathrm{B} \\
\mathrm{Bu}, \mathrm{Fl}\end{array}$ & $\begin{array}{l}\text { 1. Cut, wound } \\
\text { 2. Vomiting, nausea } \\
\text { 3. Tonsils, thyroid problem } \\
\text { 4. Dysentery in cattle }\end{array}$ & $\begin{array}{l}\mathrm{T} \\
\mathrm{O} \\
\mathrm{O} \\
\mathrm{O}\end{array}$ & $\begin{array}{l}\text { 1. Paste of root } \\
\text { 2. Powder of dry buds and root } \\
\text { 3. Decoction of bark for gargle } \\
\text { 4. Infusion of flower }\end{array}$ \\
\hline $\begin{array}{l}\text { Bridelia retusa (L.) Spreng. } \\
\text { (Phyllanthaceae) }\end{array}$ & Pleple & T & B & $\begin{array}{l}\text { 1. Burns, skin acne, cut, wound } \\
\text { 2. Bronchitis }\end{array}$ & $\begin{array}{l}\mathrm{T} \\
\mathrm{O}\end{array}$ & $\begin{array}{l}\text { 1. Paste of bark } \\
\text { 2. Decoction of bark }\end{array}$ \\
\hline Bridelia tomentosa Blume (Phyllanthaceae) & $\begin{array}{l}\text { Thebihi- } \\
\text { arong }\end{array}$ & $\mathrm{T}$ & $L, B$ & 1. Stomach ache & O & 1. Decoction of bark and leaf \\
\hline Capsicum annuum L. (Solanaceae) & $\begin{array}{l}\text { Inglong } \\
\text { abirik }\end{array}$ & $\mathrm{H}$ & $L, F$ & $\begin{array}{l}\text { 1. Dyspepsia, sore throat } \\
\text { 2. Rheumatism } \\
\text { 3. Laryngitis }\end{array}$ & $\begin{array}{l}\mathrm{O} \\
\mathrm{T} \\
\mathrm{O}\end{array}$ & $\begin{array}{l}\text { 1. Direct consumption of fruits } \\
\text { 2. Paste of fruits and leaf } \\
\text { 3. Decoction of fruits for gargle }\end{array}$ \\
\hline Careya arborea Roxb. (Lecythidaceae) & Loring & $\mathrm{T}$ & B & 1. Cure dysentery in cattle & O & 1. Juice of the bark \\
\hline Centella asiatica (L.) Urb. (Apiaceae) & Chong amok & $\mathrm{H}$ & $L, W p$ & $\begin{array}{l}\text { 1. Cut, wound, itches, sore eyes, } \\
\text { sinusitis } \\
\text { 2. Gastric problem, cold, cough } \\
\text { 3. Haemorrhoids }\end{array}$ & $\begin{array}{l}\mathrm{T} \\
\mathrm{O} \\
\mathrm{O}\end{array}$ & $\begin{array}{l}\text { 1. Juice of leaf } \\
\text { 2. Infusion of leaf } \\
\text { 3. Juice of whole plant }\end{array}$ \\
\hline $\begin{array}{l}\text { Cheilocostus speciosus (J.Koenig) C.D. } \\
\text { Specht (Costaceae) }\end{array}$ & Ai-upo & $\mathrm{H}$ & $\mathrm{Rh}$ & $\begin{array}{l}\text { 1. Helminthiasis, bronchitis } \\
\text { 2. Skin acne }\end{array}$ & $\begin{array}{l}\mathrm{O} \\
\mathrm{T}\end{array}$ & $\begin{array}{l}\text { 1. Juice of rhizome } \\
\text { 2. Paste of rhizome }\end{array}$ \\
\hline Cissampelos pareira L. (Menispermaceae) & Tubuki-lota & $C$ & $\begin{array}{l}L, R \\
\text { St }\end{array}$ & $\begin{array}{l}\text { 1. Skin acne, cut, wound, antidote } \\
\text { against insect bite } \\
\text { 2. Helminthiasis, diarrhoea, } \\
\text { dysentery, dysmenorrhoea }\end{array}$ & $\begin{array}{l}\mathrm{T} \\
\mathrm{O}\end{array}$ & $\begin{array}{l}\text { 1. Paste of leaf and root } \\
\text { 2. Infusion of leaf and stem }\end{array}$ \\
\hline
\end{tabular}


Table 3 Enumeration of medicinal plant species used by the Karbi tribe in East Karbi Anglong Wildlife Sanctuary (Continued)

\begin{tabular}{|c|c|c|c|c|c|c|}
\hline Botanical name & Local name & Habit & $\begin{array}{l}\text { Parts } \\
\text { used }\end{array}$ & Medicinal uses & $\begin{array}{l}\text { Used } \\
\text { type }\end{array}$ & Mode of application \\
\hline $\begin{array}{l}\text { Citrus assamensis R.M.Dutta \& } \\
\text { Bhattacharya (Rutaceae) }\end{array}$ & Tumeng & $\mathrm{S}$ & $\mathrm{F}$ & $\begin{array}{l}\text { 1. Dyspepsia } \\
\text { 2. Antidote against insect bite } \\
\text { 3. Malaria }\end{array}$ & $\begin{array}{l}\mathrm{O} \\
\mathrm{T} \\
\mathrm{O}\end{array}$ & $\begin{array}{l}\text { 1. Juice of fruits } \\
\text { 2. Juice of fruits } \\
\text { 3. Juice of fruits }\end{array}$ \\
\hline $\begin{array}{l}\text { Clerodendrum infortunatum } \mathrm{L} . \\
\text { (Verbenaceae) }\end{array}$ & Phlek ik & $S$ & $\begin{array}{l}\mathrm{L}, \mathrm{TW} \\
\mathrm{R}\end{array}$ & $\begin{array}{l}\text { 1. Diarrhoea, dysentery } \\
\text { 2. Dandruff }\end{array}$ & $\begin{array}{l}\mathrm{O} \\
\mathrm{T}\end{array}$ & $\begin{array}{l}\text { 1. Infusion of root and twigs } \\
\text { 2. Infusion of leaf }\end{array}$ \\
\hline Curcuma longa L. (Zingiberaceae) & Tharmit & $\mathrm{H}$ & $\mathrm{Rh}$ & $\begin{array}{l}\text { 1. Dyspepsia, gastric problem } \\
\text { 2. Rheumatism, cut, wound, bruise, } \\
\text { burns }\end{array}$ & $\begin{array}{l}\mathrm{O} \\
\mathrm{T}\end{array}$ & $\begin{array}{l}\text { 1. Juice of rhizome } \\
\text { 2. Paste of rhizome }\end{array}$ \\
\hline Datura metel L. (Solanaceae) & $\begin{array}{l}\text { Hepi } \\
\text { chumprak }\end{array}$ & $\mathrm{H}$ & L, S & $\begin{array}{l}\text { 1. Pain reliever } \\
\text { 2. Asthma and bronchitis }\end{array}$ & $\begin{array}{l}\top \\
1\end{array}$ & $\begin{array}{l}\text { 1. Paste of roasted leaf } \\
\text { 2. Vapour of boil leaf }\end{array}$ \\
\hline $\begin{array}{l}\text { Dendrocalamus strictus (Roxb.) Nees } \\
\text { (Poaceae) }\end{array}$ & Chek arong & $\mathrm{S}$ & L & 1. Arthritis, fever & $\mathrm{T}$ & 1. Paste of leaf \\
\hline $\begin{array}{l}\text { Drymaria cordata (L.) Willd. ex Roem. \& } \\
\text { Schult. (Caryophyllaceae) }\end{array}$ & Nonrongman & $\mathrm{H}$ & $W p, L$ & $\begin{array}{l}\text { 1. Cut, wound, bruise, burns } \\
\text { 2. Cold, cough, sinusitis }\end{array}$ & $\begin{array}{l}\top \\
1\end{array}$ & $\begin{array}{l}\text { 1. Paste of whole plant } \\
\text { 2. Vapour from boil leaf }\end{array}$ \\
\hline Ficus benghalensis L. (Moraceae) & $\begin{array}{l}\text { Cheri } \\
\text { hanthor }\end{array}$ & $\mathrm{T}$ & L, La & $\begin{array}{l}\text { 1. Diarrhoea, dysentery } \\
\text { 2. Haemorrhoids }\end{array}$ & $\begin{array}{l}\mathrm{O} \\
\mathrm{O}\end{array}$ & $\begin{array}{l}\text { 1. Infusion of leaf buds } \\
\text { 2. Direct consumption of a few } \\
\text { drops of latex with milk }\end{array}$ \\
\hline Ficus hispida L. (Moraceae) & Ingthum & $\mathrm{T}$ & $R, F, B$ & $\begin{array}{l}\text { 1. Skin acne, itches } \\
\text { 2. Jaundice, stomach ache } \\
\text { 3. Increase lactation in lactating } \\
\text { woman }\end{array}$ & $\begin{array}{l}\mathrm{T} \\
\mathrm{O} \\
\mathrm{O}\end{array}$ & $\begin{array}{l}\text { 1. Powder of dried root bark } \\
\text { 2. Decoction of fruits and bark } \\
\text { 3. Direct consumption of ripe } \\
\text { fruits }\end{array}$ \\
\hline Ficus racemosa L. (Moraceae) & Cheri & $\mathrm{T}$ & $\begin{array}{l}\text { B, La, } \\
F\end{array}$ & $\begin{array}{l}\text { 1. Mouth infection } \\
\text { 2. Ears infection } \\
\text { 3. Urinary disorder }\end{array}$ & $\begin{array}{l}\mathrm{O} \\
\mathrm{T} \\
\mathrm{O}\end{array}$ & $\begin{array}{l}\text { 1. Decoction of bark for gargle } \\
\text { 2. Paste of latex } \\
\text { 3. Powder of dried peel of its } \\
\text { fruits }\end{array}$ \\
\hline $\begin{array}{l}\text { Geophila repens (L.) I.M. Johnst. } \\
\text { (Rubiaceae) }\end{array}$ & Chong & $\mathrm{H}$ & $W p, F$ & $\begin{array}{l}\text { 1. Skin infection, skin acne, } \\
\text { allergies }\end{array}$ & $\mathrm{T}$ & 1. Paste of whole plant \\
\hline $\begin{array}{l}\text { Habenaria dentata (Sw.) Schltr. } \\
\text { (Orchidaceae) }\end{array}$ & Bomu & $\mathrm{H}$ & Wp & 1. Skin acne, cut, wound & $\mathrm{T}$ & 1. Paste of whole plant \\
\hline Hedyotis scandens Roxb. (Rubiaceae) & $\begin{array}{l}\text { Bi } \\
\text { akengkung }\end{array}$ & $\mathrm{H}$ & $\mathrm{R}$ & 1. Sprains in goats & $\mathrm{T}$ & 1. Paste of rhizome \\
\hline Hibiscus cannabinus L. (Malvaceae) & Hanserong & $\mathrm{H}$ & $\begin{array}{l}\mathrm{L}, \mathrm{Fl}, \\
\mathrm{S}\end{array}$ & $\begin{array}{l}\text { 1. Cold, cough } \\
\text { 2. Muscle fatigue } \\
\text { 3. Gastric problem, stomach ache }\end{array}$ & $\begin{array}{l}\mathrm{O} \\
\mathrm{T} \\
\mathrm{O}\end{array}$ & $\begin{array}{l}\text { 1. Infusion of leaf } \\
\text { 2. Paste of leaf and stem } \\
\text { 3. Juice of flower mixed with } \\
\text { sugar }\end{array}$ \\
\hline Hibiscus sabdariffa L. (Malvaceae) & $\begin{array}{l}\text { Hanserong } \\
\text { ke-er }\end{array}$ & $\mathrm{H}$ & $S, L$ & $\begin{array}{l}\text { 1. Urinary incontinence, dyspepsia } \\
\text { 2. Antidote against insect bite } \\
\text { 3. Food poisoning in cattle }\end{array}$ & $\begin{array}{l}\mathrm{O} \\
\mathrm{T} \\
\mathrm{O}\end{array}$ & $\begin{array}{l}\text { 1. Decoction of seed } \\
\text { 2. Paste of leaf } \\
\text { 3. Decoction of seed }\end{array}$ \\
\hline Hydrocotyle sibthorpioides Lam. (Apiaceae) & Chong amok & $\mathrm{H}$ & L & $\begin{array}{l}\text { 1. Dysentery, gastric problem, } \\
\text { stomach ache }\end{array}$ & $\mathrm{O}$ & 1. Juice of leaf \\
\hline $\begin{array}{l}\text { Ichnocarpus frutescens (L.) W. T. Aiton } \\
\text { (Apocynaceae) }\end{array}$ & $\begin{array}{l}\text { Parok } \\
\text { hanthor }\end{array}$ & C & $\begin{array}{l}\text { Wp, } \\
S, L\end{array}$ & $\begin{array}{l}\text { 1. Bleeding gums } \\
\text { 2. Fever, cough, dysentery } \\
\text { 3. Cut, wound, headache }\end{array}$ & $\begin{array}{l}\mathrm{O} \\
\mathrm{O} \\
\mathrm{T}\end{array}$ & $\begin{array}{l}\text { 1. Juice of whole plant } \\
\text { 2. Decoction of stem and leaf } \\
\text { 3. Paste of leaf }\end{array}$ \\
\hline Kaempferia galanga L. (Zingiberaceae) & Bithiphaknur & $\mathrm{H}$ & $\mathrm{Rh}$ & 1. Fever in cattle & $\mathrm{O}$ & 1. Juice of rhizome \\
\hline Leea indica (Burm. F.) Merr. (Vitaceae) & Gangma-chi & $S$ & $\begin{array}{l}\mathrm{R}, \mathrm{L}, \\
\mathrm{Fl}\end{array}$ & $\begin{array}{l}\text { 1. Diarrhoea, dysentery } \\
\text { 2. Skin ache }\end{array}$ & $\begin{array}{l}\mathrm{O} \\
\mathrm{T}\end{array}$ & $\begin{array}{l}\text { 1. Decoction of root } \\
\text { 2. Paste of leaf and flower }\end{array}$ \\
\hline Leucas aspera (Willd.) Link (Lamiaceae) & Han phulok & $\mathrm{H}$ & $\mathrm{L}, \mathrm{Fl}$ & $\begin{array}{l}\text { 1. Sinusitis } \\
\text { 2. Helminthiasis } \\
\text { 3. Antidote against insect bite }\end{array}$ & $\begin{array}{l}\mathrm{N} \\
\mathrm{O} \\
\mathrm{T}\end{array}$ & $\begin{array}{l}\text { 1. Juice of leaf } \\
\text { 2. Decoction of leaf and flower } \\
\text { 3. Paste of leaf }\end{array}$ \\
\hline $\begin{array}{l}\text { Lippia alba (Mill.) N.E.Br. ex Britton \& } \\
\text { P.Wilson (Verbenaceae) }\end{array}$ & $\begin{array}{l}\text { Naga } \\
\text { alopong }\end{array}$ & $S$ & L & $\begin{array}{l}\text { 1. Conjunctivitis } \\
\text { 2. Fever, stomach ache }\end{array}$ & $\begin{array}{l}\mathrm{T} \\
\mathrm{O}\end{array}$ & $\begin{array}{l}\text { 1. Juice of leaf } \\
\text { 2. Infusion of leaf }\end{array}$ \\
\hline $\begin{array}{l}\text { Magnolia hodgsonii (Hook.f. \& Thomson) } \\
\text { H.Keng (Magnoliaceae) }\end{array}$ & $\begin{array}{l}\text { Parokbithi- } \\
\text { arong }\end{array}$ & $\mathrm{T}$ & $\mathrm{B}, \mathrm{Fl}$ & $\begin{array}{l}\text { 1. Dysmenorrhoea, stomach ache, } \\
\text { dyspepsia } \\
\text { 2. Asthma, coughing }\end{array}$ & $\begin{array}{l}\mathrm{O} \\
\mathrm{O}\end{array}$ & $\begin{array}{l}\text { 1. Decoction of bark } \\
\text { 2. Decoction of flower }\end{array}$ \\
\hline Mangifera indica L. (Anacardiaceae) & Tharve & $\mathrm{T}$ & $S, L$ & $\begin{array}{l}\text { 1. Diarrhoea, haemorrhoids } \\
\text { 2. Throat infection }\end{array}$ & $\begin{array}{l}\mathrm{O} \\
\mathrm{O}\end{array}$ & $\begin{array}{l}\text { 1. Powder of dried seed } \\
\text { 2. Direct consumption of }\end{array}$ \\
\hline
\end{tabular}


Table 3 Enumeration of medicinal plant species used by the Karbi tribe in East Karbi Anglong Wildlife Sanctuary (Continued)

\begin{tabular}{|c|c|c|c|c|c|c|}
\hline Botanical name & Local name & Habit & $\begin{array}{l}\text { Parts } \\
\text { used }\end{array}$ & Medicinal uses & $\begin{array}{l}\text { Used } \\
\text { type }\end{array}$ & Mode of application \\
\hline & & & & & & young leaf \\
\hline Moringa oleifera Lam. (Moringaceae) & Sondon & $\mathrm{T}$ & B & 1. Kill maggots in cattle & $\mathrm{T}$ & 1. Paste of bark \\
\hline Murraya koenigii (L.) Spreng. (Rutaceae) & Thengsakso & S & $\mathrm{L}$ & $\begin{array}{l}\text { 1. Gastric problem, dysentery, } \\
\text { vomiting }\end{array}$ & 0 & 1. Juice of leaf \\
\hline Nyctanthes arbor-tristis L. (Oleaceae) & Hawali & $\mathrm{T}$ & $\mathrm{L}, \mathrm{Fl}$ & $\begin{array}{l}\text { 1. Malaria, constipation, } \\
\text { helminthiasis }\end{array}$ & $\mathrm{O}$ & 1. Juice of leaf and flower \\
\hline Ocimum gratissimum L. Lamiaceae) & Tulsi & $\mathrm{H}$ & L & $\begin{array}{l}\text { 1. Indigestion } \\
\text { 2. Ectoparasitic in cattle }\end{array}$ & $\begin{array}{l}\mathrm{T} \\
\mathrm{T}\end{array}$ & $\begin{array}{l}\text { 1. Infusion } \\
\text { 2. Leaf is applied directly }\end{array}$ \\
\hline $\begin{array}{l}\text { Oroxylum indicum (L.) Vent. } \\
\text { (Bignoniaceae) }\end{array}$ & Napak ban & $\mathrm{T}$ & $\begin{array}{l}\mathrm{Fl}, \mathrm{R}, \\
\mathrm{S}, \mathrm{B}\end{array}$ & $\begin{array}{l}\text { 1. Helminthiasis } \\
\text { 2. Diarrhoea, dysentery } \\
\text { 3. Cut, wound, boils } \\
\text { 4. Tonsil }\end{array}$ & $\begin{array}{l}\mathrm{O} \\
\mathrm{O} \\
\mathrm{T} \\
\mathrm{T}\end{array}$ & $\begin{array}{l}\text { 1. Decoction of flower } \\
\text { 2. Decoction of root } \\
\text { 3. Paste of young seed } \\
\text { 4. Paste of bark for gargle }\end{array}$ \\
\hline Oxalis corniculata L. (Oxalidaceae) & $\begin{array}{l}\text { Wothung- } \\
\text { mekbok }\end{array}$ & $\mathrm{H}$ & Wp, L & $\begin{array}{l}\text { 1. Helminthiasis, scurvy } \\
\text { 2. Antidote against insect bite, } \\
\text { burns, skin allergies } \\
\text { 3. Sore eyes }\end{array}$ & $\begin{array}{l}\mathrm{O} \\
\mathrm{T} \\
\mathrm{T}\end{array}$ & $\begin{array}{l}\text { 1. Infusion of whole plant } \\
\text { 2. Paste of leaf } \\
\text { 3. Juice of leaf }\end{array}$ \\
\hline $\begin{array}{l}\text { Phlogacanthus tubiflorus (Buch.-Ham. ex } \\
\text { Wall.) Nees (Acanthaceae) }\end{array}$ & Jok-aan & S & I, L & $\begin{array}{l}\text { 1. Helminthiasis } \\
\text { 2. Cold, cough, asthma }\end{array}$ & $\begin{array}{l}\mathrm{O} \\
\mathrm{O}\end{array}$ & $\begin{array}{l}\text { 1. Juice of inflorescence } \\
\text { 2. Decoction of leaf }\end{array}$ \\
\hline Phyllanthus emblica L. (Phyllanthaceae) & Thilu kame & T & $B, F$ & $\begin{array}{l}\text { 1. Nausea, vomiting } \\
\text { 2. Dysentery }\end{array}$ & $\begin{array}{l}\mathrm{O} \\
\mathrm{O}\end{array}$ & $\begin{array}{l}\text { 1. Powder of fruits } \\
\text { 2. Decoction of fruits }\end{array}$ \\
\hline Physalis peruviana L. (Solanaceae) & $\begin{array}{l}\text { Nihang } \\
\text { bokbok }\end{array}$ & $\mathrm{H}$ & L & $\begin{array}{l}1 \text { Arthritis, headache } \\
2 \text { Malaria }\end{array}$ & $\begin{array}{l}\mathrm{T} \\
\mathrm{O}\end{array}$ & $\begin{array}{l}\text { 1. Paste of leaf } \\
\text { 2. Decoction of whole plant }\end{array}$ \\
\hline $\begin{array}{l}\text { Pseudocaryopteris foetida (D.Don) } \\
\text { P.D.Cantino (Lamiaceae) }\end{array}$ & Pherklum alo & S & Wp & 1. Ectoparasitic control in poultry & $\mathrm{T}$ & $\begin{array}{l}\text { 1. Whole plant is applied } \\
\text { directly }\end{array}$ \\
\hline $\begin{array}{l}\text { Sarcochlamys pulcherrima Gaudich. } \\
\text { (Urticaceae) }\end{array}$ & Bikbik & T & $L, F$ & $\begin{array}{l}\text { 1. Diarrhoea, dysentery } \\
\text { 2. Skin ache }\end{array}$ & $\begin{array}{l}\mathrm{O} \\
\mathrm{T}\end{array}$ & $\begin{array}{l}\text { 1. Decoction of leaf } \\
\text { 2. Juice of leaf and fruits }\end{array}$ \\
\hline Senna alexandrina Mill. (Fabaceae) & Taw-eit & S & L & $\begin{array}{l}\text { 1. Constipation, release kidney } \\
\text { stone } \\
\text { 2. Skin acne, cut, wound }\end{array}$ & $\begin{array}{l}\mathrm{O} \\
\mathrm{T}\end{array}$ & $\begin{array}{l}\text { 1. Powder of dried leaf mixed } \\
\text { with hot water } \\
\text { 2. Powder of dried leaf mixed } \\
\text { with oil }\end{array}$ \\
\hline Sida acuta Burm.f. (Malvaceae) & Bijang & $S$ & $\begin{array}{l}\text { Wp, } \\
L, R\end{array}$ & $\begin{array}{l}\text { 1. Fever, dyspepsia } \\
\text { 2. Dysentery, diarrhoea } \\
\text { 3. Bleeding gum, toothache }\end{array}$ & $\begin{array}{l}\mathrm{O} \\
\mathrm{O} \\
\mathrm{T}\end{array}$ & $\begin{array}{l}\text { 1. Decoction of whole plant } \\
\text { 2. Infusion of leaf } \\
\text { 3. Paste of root }\end{array}$ \\
\hline Sida rhombifolia L. (Malvaceae) & Bijangnai & $\mathrm{H}$ & Wp & $\begin{array}{l}\text { 1. Chicken pox, burns, skin } \\
\text { allergies }\end{array}$ & $\mathrm{T}$ & 1. Paste of whole plant \\
\hline Solanum indicum L. (Solanaceae) & Hepi sokran & $\mathrm{H}$ & $F, L$ & $\begin{array}{l}\text { 1. Helminthiasis } \\
\text { 2. Fever, cold, cough }\end{array}$ & $\begin{array}{l}\mathrm{O} \\
\mathrm{O}\end{array}$ & $\begin{array}{l}\text { 1. Direct consumption of fruits } \\
\text { 2. Decoction of fruits and Leaf }\end{array}$ \\
\hline Solanum torvum Swartz (Solanaceae) & $\begin{array}{l}\text { Hipi } \\
\text { kumbong }\end{array}$ & $\mathrm{S}$ & $F, L$ & $\begin{array}{l}\text { 1. Helminthiasis } \\
\text { 2. Skin infections, cut, wound }\end{array}$ & $\begin{array}{l}\mathrm{O} \\
\mathrm{T}\end{array}$ & $\begin{array}{l}\text { 1. Direct consumption of fruits } \\
\text { 2. Paste of the leaf }\end{array}$ \\
\hline Stemona tuberosa Lour. (Stemonaceae) & Nune hiru & C & $\mathrm{F}$ & 1. Kill ingro (lice) in dogs & $\mathrm{T}$ & 1. Paste of fruits \\
\hline Syzygium cumini (L.) Skeels (Myrtaceae) & Jangmi & T & $\mathrm{S}, \mathrm{F}$ & $\begin{array}{l}\text { 1. Asthma, bronchitis } \\
\text { 2. Haemorrhoids }\end{array}$ & $\begin{array}{l}\mathrm{O} \\
\mathrm{O}\end{array}$ & $\begin{array}{l}\text { 1.Paste of fruits and seed kernel } \\
\text { 2. Direct consumption of fruits }\end{array}$ \\
\hline $\begin{array}{l}\text { Tabernaemontana divaricata (L.) R.Br. ex } \\
\text { Roem. \& Schult. (Apocynaceae) }\end{array}$ & Mir herai & S & $\begin{array}{l}\mathrm{R}, \mathrm{L} \\
\mathrm{FI}\end{array}$ & $\begin{array}{l}\text { 1. Diarrhoea, stomach ache } \\
\text { 2. Cough } \\
\text { 3. Sore eyes }\end{array}$ & $\begin{array}{l}\mathrm{O} \\
\mathrm{O} \\
\mathrm{T}\end{array}$ & $\begin{array}{l}\text { 1. Decoction of root } \\
\text { 2. Infusion of leaf } \\
\text { 3. Juice of flower }\end{array}$ \\
\hline Tephrosia purpurea (L.) Pers (Fabaceae) & Mith-arong & S & $W p, L$ & $\begin{array}{l}\text { 1. Jaundice } \\
\text { 2. Toothache }\end{array}$ & $\stackrel{\mathrm{O}}{\mathrm{T}}$ & $\begin{array}{l}\text { 1. Decoction of whole plant } \\
\text { 2. Paste of leaf }\end{array}$ \\
\hline $\begin{array}{l}\text { Terminalia arjuna Wight and Arn. } \\
\text { (Combretaceae) }\end{array}$ & Arjungos & $\mathrm{T}$ & B & $\begin{array}{l}\text { 1. Food poisoning } \\
\text { 2. Bone fracture } \\
\text { 3. Bone fracture in cattle }\end{array}$ & $\begin{array}{l}\mathrm{O} \\
\mathrm{T} \\
\mathrm{T}\end{array}$ & $\begin{array}{l}\text { 1. Infusion of bark } \\
\text { 2. Paste of the bark } \\
\text { 3. Paste of the bark }\end{array}$ \\
\hline $\begin{array}{l}\text { Terminalia bellirica (Gaertn.) Roxb. } \\
\text { (Combretaceae) }\end{array}$ & Logio-asing & $\mathrm{T}$ & $F, B$ & $\begin{array}{l}\text { 1. Diarrhoea, dysentery } \\
\text { 2. Leucodermia }\end{array}$ & $\begin{array}{l}\mathrm{O} \\
\mathrm{T}\end{array}$ & $\begin{array}{l}\text { 1. Direct consumption of the } \\
\text { pulp from raw fruits } \\
\text { 2. Paste of bark }\end{array}$ \\
\hline Tragia involucrata L. (Euphorbiaceae) & $B a b$ & $\mathrm{H}$ & $\mathrm{R}$ & 1. Cure helminthiasis in dogs & $\mathrm{O}$ & 1. Paste of rhizome \\
\hline
\end{tabular}


Table 3 Enumeration of medicinal plant species used by the Karbi tribe in East Karbi Anglong Wildlife Sanctuary (Continued)

\begin{tabular}{|c|c|c|c|c|c|c|}
\hline Botanical name & Local name & Habit & $\begin{array}{l}\text { Parts } \\
\text { used }\end{array}$ & Medicinal uses & $\begin{array}{l}\text { Used } \\
\text { type }\end{array}$ & Mode of application \\
\hline & kangsam & & & & & \\
\hline Zanthoxylum armatum DC. (Rutaceae) & Jajur & S & L & 1. Cure helminthiasis in cattle & $\mathrm{O}$ & 1. Paste of leaf \\
\hline $\begin{array}{l}\text { Zingiber chrysanthum Roscoe } \\
\text { (Zingiberaceae) }\end{array}$ & Sobleksin & $\mathrm{H}$ & $\mathrm{Rh}$ & $\begin{array}{l}\text { 1. Ear infection, boils, skin acne, } \\
\text { cut, wound }\end{array}$ & $\mathrm{T}$ & 1. Paste of rhizome \\
\hline Zingiber officinale Rosc. (Zingiberaceae) & Hanso & $\mathrm{H}$ & $\mathrm{Rh}$ & $\begin{array}{l}\text { 1. Haemorrhoids, constipation } \\
\text { 2. Dysmenorrhoea, stomach ache } \\
\text { 3. Bleeding gums and ear } \\
\text { infection } \\
\text { 4. Indigestion in cattle }\end{array}$ & $\begin{array}{l}\mathrm{O} \\
\mathrm{O} \\
\mathrm{T} \\
\mathrm{O}\end{array}$ & $\begin{array}{l}\text { 1. Juice of rhizome } \\
\text { 2. Decoction of rhizome } \\
\text { 3. Paste of rhizome } \\
\text { 4. Decoction of rhizome }\end{array}$ \\
\hline $\begin{array}{l}\text { Zizyphus xylopyrus (Retz) Willd. } \\
\text { (Rhamnaceae) }\end{array}$ & Bukuri arong & $\mathrm{T}$ & $F, S, L$ & $\begin{array}{l}\text { 1. Diarrhoea } \\
\text { 2. Headache, fever } \\
\text { 3. Skin burn and infection in cattle }\end{array}$ & $\begin{array}{l}\mathrm{O} \\
\mathrm{T} \\
\mathrm{T}\end{array}$ & $\begin{array}{l}\text { 1. Powder of seed } \\
\text { 2. Paste of leaf } \\
\text { 3. Paste of leaf }\end{array}$ \\
\hline
\end{tabular}

Seven out of the 14 villages were selected for the study, namely Borpung, Tarapung, Noralangso, Phanglangso, Langtuk hanse, Kanduwa bosti, and Langpratlangso (Table 1). These villages were purposively selected for their high tendency to use non-timber forest resources from the sanctuary. Selection of respondents was done through purposive stratified sampling from those villagers who accepted the request for an interview of their own free will. A total of 70 respondents (49 males and 21 females) from 70 households, i.e. 1 respondent from each house, were interviewed for the study. Two male forest officials were also included among the 49 male respondents, and they were from 1 of the selected villages (Borpung) representing 2 households from the village. The interviewed respondents were mainly the eldest persons in the household. Information regarding NTFPs harvested and their quantities, together with demographic details of the collector, was collected from the sample households through interviews by participatory interaction method supplemented by group discussions and semi-structured questionnaire (Martin 1995; Alexiades and Sheldon 1996).

\section{Collection and identification of NTFPs}

Collection of NTFPs was done in the company of respondents. Collection, pressing, and preparation of herbarium specimens were done following the methods suggested by Jain and Rao (1977) with suitable modifications. The collected specimens were identified with the help of available published literature (Kanjilal et al. 1939; Balakrishnan 1983; Haridasan and Rao 1987), as well as in consultation with experts from the herbarium housed at the Botanical Survey of India, Eastern Circle, Shillong (ASSAM), and the herbaria of the Department of Botany, North-Eastern Hill University. The scientific names were validated using the International Plant Names Index (IPNI) and an online resource, The PlantList (TPL).

\section{Data analysis}

Data collected was analysed using four quantitative indices: use report (UR), use value (UV), informant consensus factor (ICF), and fidelity level (FL). Whenever a plant was mentioned as being used for a particular purpose, it was considered to be one UR (Amiguet et al. 2005). The relative importance was analysed using the use value (UV), a quantitative measure for the relative importance of a species, which is based on the number of uses and the number of people that cite a given plant indicating the species that are considered most important by a given population (Phillips and Gentry 1993).

$\mathrm{UV}$ is calculated using the following formula:

$$
\mathrm{UV}=U / n
$$

where $U$ is the number of use reports cited by every respondent for a given species and $n$ is the total number of respondents interviewed. The UV is high when there are many use reports for a given species, which implies that the taxa are important. When there are few reports related to its use, the UV decreases.

The informant consensus factor (ICF) was calculated as:

$$
\mathrm{ICF}=(N u r-\mathrm{Ns}) /(N u r-1)
$$

where 'Nur' is the number of use reports for a particular use category and 'Ns' is the number of species used, for each category mentioned by all respondents (Trotter and Logan 1986). ICF was used to test the homogeneity of knowledge about the plants. Before performing the analysis, all the ailments were broadly classified into various categories following Hussain et al. (2018). ICF gives information about the consensus of respondents regarding the utilisation of a certain use category. The data of this factor ranges from 0 to 1 . Values close to 1 indicate high consensus agreement among the respondents for the use of the particular plant while a value close to 0 indicates least consensus agreement. 
Table 4 Enumeration of edible plants used by the local people in East Karbi Anglong Wildlife Sanctuary

\begin{tabular}{|c|c|c|c|c|}
\hline Scientific name & Local name & Habit & $\begin{array}{l}\text { Parts } \\
\text { used }\end{array}$ & Form of use or eaten \\
\hline Aegle marmelos (L.) Corrêa (Rutaceae) & Thepli & $\mathrm{T}$ & $\mathrm{F}$ & Ripe fruits are eaten directly. \\
\hline Alocasia macrorrhiza Schott (Araceae) & Hensoksu & $\mathrm{H}$ & $\mathrm{Rh}$ & Rhizomes are eaten, baked, or roasted. \\
\hline Alpinia nigra (Gaertn.) Butt (Zingiberaceae) & Tara & $\mathrm{H}$ & St & Stems are cooked as curry. \\
\hline Amaranthus spinosus L. (Amaranthaceae) & Dido & $\mathrm{H}$ & Sh & Shoots are made as curry. \\
\hline Amorphophallus bulbifer (Roxb.) Blume & Hensarku & $\mathrm{H}$ & P & Petioles are eaten, roasted, or boiled. \\
\hline Artocarpus chama Buch.-Ham. (Moraceae) & Phong & $\mathrm{T}$ & $F, S$ & Ripe fruits are eaten directly and seeds are roasted. \\
\hline Artocarpus heterophyllus Lam. (Moraceae) & Jangphong & $\mathrm{T}$ & $F, S$ & Ripe fruits are eaten directly and seeds are boiled. \\
\hline Artocarpus lacucha Buch.-Ham. (Moraceae) & Arong & $\mathrm{T}$ & $\mathrm{F}$ & Ripe fruits are eaten directly. \\
\hline Averrhoa carambola L. (Oxalidaceae) & Torte & $\mathrm{T}$ & $\mathrm{F}$ & Fruits are eaten directly or by making curry. \\
\hline Annona reticulata L. (Annonaceae) & $\begin{array}{l}\text { Longle } \\
\text { jangphong }\end{array}$ & $\mathrm{T}$ & $\mathrm{F}$ & Ripe fruits are eaten directly. \\
\hline Baccaurea ramiflora Lour. (Phyllanthaceae) & Dampejuk & $\mathrm{T}$ & $\mathrm{F}$ & Ripe fruits are eaten directly. \\
\hline Calamus erectus Roxb. (Arecaceae) & Theng & $S$ & $\mathrm{~F}$ & Ripe fruits are eaten directly. \\
\hline $\begin{array}{l}\text { Castanopsis indica (Roxb. ex Lindl.) A.DC. } \\
\text { (Fagaceae) }\end{array}$ & Phongrong & $\mathrm{T}$ & S & Seeds are eaten raw or roasted. \\
\hline $\begin{array}{l}\text { Choerospondias axillaris (Roxb.) B.L.Burtt \& } \\
\text { A.W.Hill (Anacardiaceae) }\end{array}$ & Thesili & $\mathrm{T}$ & $\mathrm{F}$ & Ripe fruits are eaten directly. \\
\hline Coix lacryma-jobi L. (Poaceae) & Tumdak & $\mathrm{H}$ & S & Seed are roasted. \\
\hline Colocasia esculenta (L.) Schott (Araceae) & Henru ke-ik & $\mathrm{H}$ & Tu & Tubers eaten as boiled and curry. \\
\hline Cucumis melo L. (Cucurbitaceae) & Thoithe suri & $\mathrm{H}$ & $\mathrm{F}$ & Ripe fruits are eaten directly. \\
\hline $\begin{array}{l}\text { Dendracalamus hamiltonii Nees et Arn. ex } \\
\text { Munro (Poaceae) }\end{array}$ & Kaipho & B & Sh & Fermented shoots are eaten as curry. \\
\hline Dillenia indica L. (Dilleniaceae]) & Plum-plam & $\mathrm{T}$ & $\mathrm{F}$ & Fruits are eaten as curry. \\
\hline Dillenia pentagyna Roxb. (Dilleniaceae) & Cherimpi & $\mathrm{T}$ & $\mathrm{F}$ & Fruits are eaten directly. \\
\hline Dioscorea alata L. (Dioscoreaceae) & Ruichin & $\mathrm{H}$ & T & Tubers eaten as boiled and curry. \\
\hline $\begin{array}{l}\text { Engelhardtia spicata Lechen ex Blume } \\
\text { (Juglandaceae) }\end{array}$ & Marloo & $\mathrm{T}$ & $\mathrm{F}$ & Ripe fruits are eaten directly. \\
\hline $\begin{array}{l}\text { Garcinia pedunculata Roxb. ex Buch.- } \\
\text { Ham.(Clusiaceae) }\end{array}$ & Pranpre & $\mathrm{T}$ & $\mathrm{F}$ & Ripe fruits are eaten directly. \\
\hline Gnetum gnemon L.(Gnetaceae) & Hanthu & S & L, S & Leaves are eaten as curry and seeds are fried. \\
\hline Hibiscus sabdariffa L.(Malvaceae) & $\begin{array}{l}\text { Hanserong } \\
\text { ke-er }\end{array}$ & S & $\mathrm{F}$ & Fruits are eaten as curry. \\
\hline $\begin{array}{l}\text { Hodgsonia macrocarpa (Blume) } \\
\text { Cogn.(Cucurbitaceae) }\end{array}$ & Hanthar & C & S & Seeds are eaten raw or roasted. \\
\hline $\begin{array}{l}\text { Melastoma nepalensis Lodd. } \\
\text { (Melastomataceae) }\end{array}$ & Bik bik & S & $\mathrm{F}$ & Ripe fruits are eaten directly. \\
\hline Murraya koenigii (L.) Spreng. (Rutaceae) & Thengsakso & S & L & Leaves are eaten as curry. \\
\hline Musa paradisiaca L.(Musaceae) & Lothe & $\mathrm{H}$ & $F, \ln$ & $\begin{array}{l}\text { Ripe fruits are eaten directly, unripe fruits and inflorescence are eaten, } \\
\text { roasted, or boiled. }\end{array}$ \\
\hline Musa balbisiana Colla(Musaceae) & Lobong & $\mathrm{H}$ & $F, \ln$ & Ripe fruits and inflorescence are eaten as boiled or curry. \\
\hline Mussaenda isertiana DC. (Rubiaceae) & Vosopeban & S & L & Tender leaves are eaten with meat. \\
\hline Olax acuminata Wall, ex Benth. (Olacaceae) & Hanboka & S & L & Leaves are eaten boiled. \\
\hline $\begin{array}{l}\text { Oreocnide integrifolia (Gaudich.) } \\
\text { Miq.(Urticaceae) }\end{array}$ & Thehoi & S & $\ln$ & Inflorescences are cooked with meat or fish. \\
\hline Oroxylum indicum (L.) Kurz (Bignoniaceae) & Nopakban & $\mathrm{T}$ & $\mathrm{Fl}$, Sh & Flowers and shoots mixed with dried fish to make chutney. \\
\hline Paederia foetida L. (Rubiaceae) & $\begin{array}{l}\text { Rikang } \\
\text { menthu }\end{array}$ & C & L & Leaves are cooked with fish or meat. \\
\hline Parkia timoriana (DC.) Merr. (Fabaceae) & Themuke & $\mathrm{T}$ & $\mathrm{F}$ & Fruits are baked and eaten as chutney. \\
\hline
\end{tabular}


Table 4 Enumeration of edible plants used by the local people in East Karbi Anglong Wildlife Sanctuary (Continued)

\begin{tabular}{|c|c|c|c|c|}
\hline Scientific name & Local name & Habit & $\begin{array}{l}\text { Parts } \\
\text { used }\end{array}$ & Form of use or eaten \\
\hline Passiflora foetida L. (Passifloraceae) & Thevu-um & $\mathrm{H}$ & $\mathrm{F}$ & Ripe fruits are eaten directly. \\
\hline $\begin{array}{l}\text { Phlogacanthus curviflorus (Wall.) Nees } \\
\text { (Acanthaceae) }\end{array}$ & Jok an & S & $\ln$ & Inflorescences are eaten boiled or baked. \\
\hline Phlogacanthus thyrsiflorus Nees (Acanthaceae) & Jok-an & S & In & $\begin{array}{l}\text { Inflorescences are boiled with dried fish or baked and eaten as } \\
\text { chutney. }\end{array}$ \\
\hline Phyllanthus acidus (L.) Skeels (Phyllanthaceae) & Takiri thelu & $\mathrm{T}$ & $\mathrm{F}$ & Fruits are eaten directly. \\
\hline Phyllanthus emblica L. (Phyllanthaceae) & Thelu kame & $\mathrm{T}$ & $\mathrm{F}$ & Fruits are eaten raw. \\
\hline Physalis peruviana L. (Solanaceae) & Bokbok & $\mathrm{H}$ & $\mathrm{F}$ & Ripe fruits are eaten directly. \\
\hline Piper thomsonii (C. DC.) Hook. f. (Piperaceae) & Hanbithi & C & $L, S$ & $\begin{array}{l}\text { Leaves are cooked with rice flour and eaten as curry, dried seeds are } \\
\text { added to curry to give flavour. }\end{array}$ \\
\hline $\begin{array}{l}\text { Polygonum microcephalum D. Don } \\
\text { (Polygonaceae) }\end{array}$ & Delap & $\mathrm{H}$ & L & Leaves are cooked with fish. \\
\hline $\begin{array}{l}\text { Rhynchotechum ellipticum (Wall, ex Dietr.) A. } \\
\text { DC. (Gesneriaceae) }\end{array}$ & Mehek & $\mathrm{H}$ & L & Leaves are eaten as boiled or curry. \\
\hline $\begin{array}{l}\text { Sauropus androgynus (L.) Merr. } \\
\text { (Phyllanthaceae) }\end{array}$ & Hanvoti & $\mathrm{T}$ & L & Leaves cooked as curry. \\
\hline Sesamum abbreviatum Merxm. (Pedaliaceae) & Nempo & $\mathrm{H}$ & $L, S$ & Leaves and seeds are used for making curry. \\
\hline Solanum indicum Linn. (Solanaceae) & Hepi sokran & S & L & Leaves are eaten as curry. \\
\hline Sterculia villosa Roxb. (Malvaceae) & Jintekong & $\mathrm{T}$ & $S$ & Roasted seeds are eaten. \\
\hline Streblus asper Lour. (Moraceae) & Cheri theso & $\mathrm{T}$ & $\mathrm{F}$ & Ripe fruits are eaten directly. \\
\hline Syzygium cumini (L.) Skeels, (Myrtaceae) & Jangmi & T & F & Ripe fruits are eaten directly. \\
\hline $\begin{array}{l}\text { Trevesia palmata (Roxb. ex Lindl.) Vis. } \\
\text { (Araliaceae) }\end{array}$ & Kokterak & S & In & Inflorescences are boiled and eaten as chutney. \\
\hline Zanthoxylum rhetsa (Roxb.) DC (Rutaceae) & $\begin{array}{l}\text { Arioso } \\
\text { hanjor }\end{array}$ & $\mathrm{T}$ & L, Sh & Leaves and shoots are used to make curry. \\
\hline Zingiber chrysanthum Rosc. (Zingiberaceae) & Sobleksin & $\mathrm{H}$ & $\mathrm{F}$ & Fruits are eaten as fried. \\
\hline Zingiber rubens Roxb. (Zingiberaceae)f & $\begin{array}{l}\text { Phree } \\
\text { kangnek }\end{array}$ & $\mathrm{H}$ & Sh & Shoots are cooked with dried fish. \\
\hline $\begin{array}{l}\text { Zingiber zerumbet (L.) Rose, ex Seem. } \\
\text { (Zingiberaceae) }\end{array}$ & Vorek hanso & $\mathrm{H}$ & $L, \ln$ & Leaves and inflorescences are cooked with dried fish. \\
\hline Zizyphus xylopyrus (Retz) Willd. (Rhamnaceae) & Bukuri arong & $\mathrm{T}$ & $\mathrm{F}$ & Fruits are cooked as curry. \\
\hline
\end{tabular}

Fidelity level (FL) was calculated as:

$$
\mathrm{FL}(\%)=\mathrm{Np} / \mathrm{N} \times 100
$$

where ' $\mathrm{Np}$ ' is the number of respondents that claim to use a plant species for treating a particular disease and $N$ is the number of respondents that use the plants as a medicine to treat any given disease (Alexiades 1996).

\section{Analysis of percentage contribution of NTFPs to household income}

Household income from the 70 respondents was calculated as the sum incomes of all the members of a particular household. It includes income from off-farm activities, agricultural incomes, and forest incomes (Endamana et al. 2016).

The mathematical presentation is as follows:

$$
\mathrm{THI}=\mathrm{OFI}+\mathrm{Al}+\mathrm{FI}
$$

where $\mathrm{THI}=$ total household income, OFI $=$ off-farm income, $\mathrm{AI}=$ agricultural income, and $\mathrm{FI}=$ forest income. The per capita household income (monthly) was calculated with the total gross household income divided by the total number of family members residing together under the same house.

\section{Analysis of NTFP collector's percentage based on gender typology}

The percentage of gender categorisation regarding the collection of NTFPs was calculated from the total respondents interviewed, both male and female. It is based on their practice of collection of edible forest products, ethnomedicines, household building materials and utensils, spices and condiments, and herbal dyes from the study site. 
Table 5 Enumeration of household building materials and utensils used by the Karbi tribe in East Karbi Anglong Wildlife Sanctuary

\begin{tabular}{|c|c|c|c|c|}
\hline Scientific name & $\begin{array}{l}\text { Local } \\
\text { name }\end{array}$ & Habit & $\begin{array}{l}\text { Parts } \\
\text { used }\end{array}$ & Uses \\
\hline Abrus precatorius L. (Fabaceae) & Chuselok & $\mathrm{S}$ & S & $\begin{array}{l}\text { Seeds are used to make eyes of birds in the traditional wood } \\
\text { craft Jambili Athon. }\end{array}$ \\
\hline Areca catechu L. (Arecaceae) & Kove & $\mathrm{T}$ & St & Wood is used for making harpi, a weaving implement. \\
\hline Artocarpus chama Buch.-Ham. (Moraceae) & Phong & $\mathrm{T}$ & St & Wood is used for making long, a traditional wooden mortar. \\
\hline Bambusa afjinis Munro (Poaceae) & Inghin & B & St & Roof of house \\
\hline Bambusa pallida Munro (Poaceae) & Chek duk & B & St & Used for roofing and also used as knife handle \\
\hline Bambusa tulda Roxb. (Poaceae) & Artungso & B & St & Used for roofing and as fishing rod \\
\hline Bauhinia variegata L. (Fabaceae) & Ingku & $\mathrm{T}$ & St & Used as post for making house \\
\hline Calamus erectus Roxb. (Arecaceae) & Theng & $\mathrm{S}$ & St & Stem with bamboo are used to make various basket. \\
\hline Callicarpa arborea Roxb. (Lamiaceae) & Arhi & $\mathrm{T}$ & St & Used as post for making house \\
\hline Careya arborea Roxb. (Lecythidaceae) & Loring & $\mathrm{T}$ & St & Used as post for making house \\
\hline Cassia fistula L. (Fabaceae) & Honaru & $\mathrm{T}$ & St & Used as post for making house \\
\hline Castanopsis indica (Roxb. ex Lindl.) A.DC. (Fagaceae) & Phongrong & $\mathrm{T}$ & St & Used as post for making house \\
\hline Dalbergia sisso Roxb. (Fabaceae) & $\begin{array}{l}\text { Subin } \\
\text { rikang }\end{array}$ & $\mathrm{T}$ & St & Stem is used for anghoi (base) of baskets. \\
\hline $\begin{array}{l}\text { Dendracalamus hamiltonii Nees et Arn. ex Munro } \\
\text { (Poaceae) }\end{array}$ & Kaipho & B & St & Stem split called jintak is used for making various crafts. \\
\hline Dipteris wallichii (R. Br.) T. Moore (Dipteridaceae) & Lodiphlir & $\mathrm{S}$ & L & Used for thatching hut in rearing domestic animals \\
\hline Garuga pinnata Roxb. (Burseraceae) & Timur & $\mathrm{T}$ & St & Used as post for making house \\
\hline Hibiscus sabdariffa L. (Malvaceae) & Hanserong & $\mathrm{S}$ & B & Used as fibre in building house \\
\hline Livistona jenkinsiana Griff. (Arecaceae) & Jasera & $\mathrm{T}$ & $\mathrm{L}$ & Used for thatching houses \\
\hline Mangifera indica L. (Anacardiaceae) & Therve & $\mathrm{T}$ & St & Wood is used for making long, a wooden mortar. \\
\hline Mesua ferrea L. (Calophyllaceae) & Mir charne & $\mathrm{T}$ & St & Wood is used for making knife handle. \\
\hline Phrynium pubinerve Blume (Marantaceae) & Loru & $\mathrm{H}$ & $\mathrm{L}$ & Used for packing kitchen items \\
\hline Sterculia villosa Roxb. (Malvaceae) & Jintekong & $\mathrm{T}$ & B & Used as fibre \\
\hline $\begin{array}{l}\text { Terminalia myriocarpa Van Heurck \& Müll. Arg. } \\
\text { (Combretaceae) }\end{array}$ & Turtung & $\mathrm{T}$ & St & Used as post for making house \\
\hline Trema orientalis (L.) Blume (Cannabaceae) & Rampak & $\mathrm{T}$ & B & Used as fibre \\
\hline $\begin{array}{l}\text { Wrightia coccinea (Roxb. ex Hornem.) Sims } \\
\text { (Apocynaceae) }\end{array}$ & $\begin{array}{l}\text { Bengwoi } \\
\text { Ke-er }\end{array}$ & $\mathrm{T}$ & St & Stem is used for making a woodcraft Jambili Athon. \\
\hline
\end{tabular}

\section{Results}

A total of 138 NTFPs plant species belonging to 59 families and 110 genera were collected from the East Karbi Anglong Wildlife Sanctuary. The highest number of NTFPs was extracted from trees (38\%), followed by herbs (32\%) and shrubs (23\%), and the least was from climbers (7\%) (Fig. 2). Out of the reported 138 NTFPs, 72 species $(42 \%)$ had ethnomedicinal importance, 57 species (33\%) are used as edible forest products, 25 species (15\%) account for household building materials and utensils, 10 species (6\%) are used as spices and condiments, and 7 species (4\%) are used as herbal dyes (Fig. 3) (Tables 2, 3, 4, $5,6,7,8$, and 9). Several species used in traditional medicine and as edible food are in high demand in the local markets (Table 10). These include Aegle marmelos, Alocasia macrorrhiza, Alpinia nigra,
Averrhoa carambola, Baccaurea ramiflora, Citrus assamensis, Dendracalamus hamiltonii, Dillenia indica, Dioscorea alata, Gnetum gnemon, etc.

The statistical evaluation report of ethnomedicines was classified into 2 major categories and 25 subcategories with regard to various ailments:

a) Traditional medicine for human ailments

The sub-categories are as follows: cephalalgia; blood and circulatory problems; cold and cough; cuts and wounds; dermatological infections; ENT diseases; eye disease; fever; gastrointestinal disease; liver diseases; malaria; menstrual problems; dental and gum problems; muscle, bones, and joints; insect stings and bites; urinary tract and kidney problems; deworming; respiratory problems; and health tonic. 
Table 6 Enumeration of spices and condiments used by the Karbi tribe in East Karbi Anglong Wildlife Sanctuary

\begin{tabular}{|c|c|c|c|c|}
\hline Scientific name & $\begin{array}{l}\text { Local } \\
\text { name }\end{array}$ & Habit & $\begin{array}{l}\text { Part } \\
\text { used }\end{array}$ & Uses \\
\hline $\begin{array}{l}\text { Aralia armata (Wall. ex G.Don) Seem. } \\
\text { (Araliaceae) }\end{array}$ & Tengnang & S & L & Aromatic leaves are cooked with meat or fish. \\
\hline Boesenbergia rotunda (L.) Mansf. (Zingiberaceae) & Tiha & $\mathrm{H}$ & $\mathrm{R}$ & Tuberous roots are used as traditional spice in most of the dishes. \\
\hline $\begin{array}{l}\text { Clinopodium umbrosum (M.Bieb.) Kuntze } \\
\text { (Lamiaceae) }\end{array}$ & Berai & $\mathrm{H}$ & Sh & Shoots are cooked with fishes. \\
\hline $\begin{array}{l}\text { Citrus assamensis R.M.Dutta \& Bhattacharya } \\
\text { (Rutaceae) }\end{array}$ & Tumeng & $\mathrm{S}$ & L & Leaves are added to flavour meat. \\
\hline Piper nigrum L. (Piperaceae) & Ahom birik & C & $\mathrm{F}$ & Dried fruits are added in many dishes as spice. \\
\hline $\begin{array}{l}\text { Dendracalamus hamiltonii Nees et Arn. ex } \\
\text { Munro (Poaceae) }\end{array}$ & Kaipho & B & Sh & $\begin{array}{l}\text { Fermented shoots called upthor are used to flavour meat and fish } \\
\text { delicacies. }\end{array}$ \\
\hline Murraya koenigii (L.) Spreng. (Rutaceae) & Thengsakso & $\mathrm{S}$ & L & Leaves are added to flavour meat and fishes. \\
\hline Sesamum abbreviatum Merxm. (Pedaliaceae) & Nempo & $\mathrm{H}$ & S & $\begin{array}{l}\text { Seeds are the most common condiment, powder seeds are eaten } \\
\text { with meat and fish. }\end{array}$ \\
\hline Zingiber officinale Rosc. (Zingiberaceae) & Hanso & $\mathrm{H}$ & $\mathrm{Rh}$ & Rhizomes are made as a paste to flavour meat or fish curry. \\
\hline Zanthoxxlum rhetsa (Roxb.) DC (Rutaceae) & $\begin{array}{l}\text { Arioso } \\
\text { hanjor }\end{array}$ & $\mathrm{T}$ & Sh, L & $\begin{array}{l}\text { Shoots and tender leaves are used to flavour dishes, particularly meat } \\
\text { items. }\end{array}$ \\
\hline
\end{tabular}

b) Ethnoveterinary medicines

The sub-categories are as follows: ectoparasitic control, deworming, dermatological infections, gastrointestinal disease, fever, and muscle, bones, and joints.

Use value (UV) of all the 138 reported species ranges from 0.014 to 0.128 (Table 11). The ICF value for traditional medicines varied from 0.11 to 0.95 , with an average value of 0.53 . Menstrual problems have the highest ICF value of 0.95 with 63 use reports for 4 species, followed by malaria ( $\mathrm{ICF}=0.93 ; 50$ use reports, 4 species), ectoparasitic control (ICF $=0.91 ; 50$ use reports, 5 species), insect stings and bites (ICF $=0.88$; 63 use reports, 8 species), etc. (Table 8 ). The species responsible for the high consensus for menstrual problems are Abroma augustum, Magnolia hodgsonii, Cissampelos pareira, and Zingiber officinale. Similarly, species responsible for the high consensus for malaria are $\mathrm{Nyc}$ tanthes arbor-tristis, Abrus precatorius, Citrus assamensis, Physalis peruviana, etc. (Table 3).

To determine the cultural importance of medicinal species in the society, the fidelity level (FL) of plants was calculated based on user reports for being used against a given ailment. The high value of fidelity level (\%) is taken for selecting the most preferred plant species for each ailment category (Uddin and Hassan 2014). The results revealed that out of the 4 highest values of ICF species for treating menstrual problems, Abroma augustum (L.) L. f. is the most commonly used species in the study area $(\mathrm{ICF}=0.95)$ with 63 use report and FL value (90\%). Similarly, Amaranthus spinosus L. is the most widely used

Table 7 Enumeration of dye-yielding plants used by the Karbi tribe in East Karbi Anglong Wildlife Sanctuary

\begin{tabular}{|c|c|c|c|c|}
\hline Scientific name & Local name & Habit & $\begin{array}{l}\text { Parts } \\
\text { used }\end{array}$ & Uses \\
\hline Croton caudatus Geisel. (Euphorbiaceae) & So-ik & $\mathrm{T}$ & St & Dye obtained is used in the traditional wooden craft Jambili Athon. \\
\hline Curcuma longa L. (Zingiberaceae) & Thermit & $\mathrm{H}$ & $\mathrm{Rh}$ & Yellow dye is used in weaving garment products. \\
\hline Ehretia acuminata R.Br. (Boraginaceae) & Chorsim & T & $\mathrm{F}, \mathrm{L}$ & $\begin{array}{l}\text { Dye extracted from it is used in colouring hijap (hand fan), tarso (small } \\
\text { mat), and jambili (traditional bags). }\end{array}$ \\
\hline $\begin{array}{l}\text { Garcinia xanthochymus Hook.f. ex } \\
\text { T.Anderson (Clusiaceae) }\end{array}$ & Tichamprang & T & $\mathrm{F}$ & Yellow dye extracted is used in colouring yarns and garments. \\
\hline Indigofer tinctoria L. (Fabaceae) & Duli & S & $\mathrm{L}, \mathrm{Fl}$ & Both the parts are said to give brownish tinge to garments. \\
\hline $\begin{array}{l}\text { Strobilanthes cusia (Nees) Kuntze Brem. } \\
\text { (Acanthaceae) }\end{array}$ & Burot & $\mathrm{H}$ & Tw & $\begin{array}{l}\text { Indigo dye is obtained and used to dye various traditional clothes among } \\
\text { the Karbi tribe. }\end{array}$ \\
\hline $\begin{array}{l}\text { Terminalia bellirica (Gaertn.) Roxb. } \\
\text { (Combretaceae) }\end{array}$ & Kuru & T & $\mathrm{F}$ & Dye obtained are rubbed on fibres or ropes to give black colour. \\
\hline
\end{tabular}

$T$ tree, $H$ herb, $S$ shrub, $C$ climber, $L$ leaves, $R$ root, $B$ bark, $F$ fruits, St stem, $P$ petioles, Sh shoot, $R h$ rhizome, Wp whole plant, $F /$ flower, $B u$ bud, Tu tuber, Tw twig, In inflorescence, La latex, Co corm, $O$ oral, $T$ topical, $N$ nasal, I inhaling 
Table 8 Consensus of agreement on the uses of medicinal plants among informants

\begin{tabular}{|c|c|c|c|c|}
\hline Category of indigenous use & Sub-categories & Number of species (Ns) & Number of use report (Nur) & Consensus factor \\
\hline \multirow[t]{19}{*}{ Human } & Cephalalgia & 6 & 15 & 0.65 \\
\hline & Blood and circulatory problems & 7 & 33 & 0.81 \\
\hline & Cold and cough & 16 & 32 & 0.51 \\
\hline & Cuts and wounds & 20 & 42 & 0.54 \\
\hline & Dermatological infections & 33 & 61 & 0.46 \\
\hline & ENT problems & 11 & 44 & 0.77 \\
\hline & Eye disease & 10 & 52 & 0.81 \\
\hline & Fever & 8 & 14 & 0.47 \\
\hline & Gastrointestinal disease & 53 & 60 & 0.11 \\
\hline & Liver disease & 2 & 4 & 0.67 \\
\hline & Malaria & 4 & 50 & 0.93 \\
\hline & Menstrual problems & 4 & 63 & 0.95 \\
\hline & Dental and gum problems & 8 & 16 & 0.53 \\
\hline & Muscle, bones, and joints & 8 & 39 & 0.81 \\
\hline & Insect stings and bites & 8 & 63 & 0.88 \\
\hline & Urinary tract and kidney problems & 6 & 11 & 0.50 \\
\hline & Deworming & 10 & 21 & 0.5 \\
\hline & Respiratory problems & 7 & 17 & 0.63 \\
\hline & Health tonic & 2 & 5 & 0.75 \\
\hline \multirow[t]{6}{*}{ Animals } & Ectoparasitic control & 5 & 50 & 0.91 \\
\hline & Deworming & 2 & 6 & 0.80 \\
\hline & Dermatological infections & 6 & 18 & 0.71 \\
\hline & Fever & 2 & 5 & 0.75 \\
\hline & Gastrointestinal disease & 6 & 25 & 0.80 \\
\hline & Muscles, bones, and joints & 2 & 5 & 0.75 \\
\hline
\end{tabular}

species for treating insect stings and bites with 62 use report and FL value (88.57\%), followed by Geophila repens (L.) I. M. Johnst. with 61 use report and FL value (87.15\%) for skin infections, Aegle marmelos (L.) Corrêa with 60 use report and FL value (85.72\%) for dysentery, and Abrus precatorius L. with 50 use report and FL value (71.42\%) for malaria (Table 9).

\section{Percentage contribution of non-timber forest products to} household incomes

The contribution of NTFPs to household incomes per month revealed that $50 \%$ of the respondents derived $50-90 \%$ of their total revenues from NTFPs, whereas about $30 \%$ derived $20-40 \%$ of their total household incomes from sales of NTFPs. While the remaining

Table 9 Fidelity level (FI \%) of frequently cited plant species with major uses

\begin{tabular}{llll}
\hline Botanical name & Categories & Citation for particular disease (use report) & Fidelity level (\%) \\
\hline Abroma augustum (L.) L.f. (Sterculiaceae) & Menstrual disorder & 63 & 90 \\
Geophila repens (L.) I.M. Johnst. (Rubiaceae) & Skin infections & 61 & 87.15 \\
Aegle marmelos (L.) Correa (Rutaceae) & Dysentery & 60 & 85.72 \\
Abrus precatorius L. (Fabaceae) & Malaria & 50 & 71.42 \\
Cheilocostus speciosus (J.Koenig) C.D. Specht (Costaceae) & Helminthiasis & 45 & 64.29 \\
Baccaurea ramiflora Lour. (Phyllanthaceae) & Scurvy & 40 & 57.15 \\
Syzygium cumini (L.) Skeels (Myrtaceae) & Haemorrhoids & 35 & 50 \\
Amaranthus spinosus L. (Amaranthaceae) & Insect stings and bites & 62 & 88.57 \\
\hline
\end{tabular}


Table 10 Documented list of traded species in the markets locally available with prevailing price

\begin{tabular}{|c|c|c|c|c|}
\hline \multirow[t]{2}{*}{ Botanical name } & \multirow[t]{2}{*}{ Part(s) traded } & \multicolumn{2}{|c|}{ Trade category } & \multirow{2}{*}{$\begin{array}{l}\text { Market price in per unit (Indian rupees) } \\
\text { Village market }\end{array}$} \\
\hline & & Food & Medicine & \\
\hline Aegle marmelos (L.) Correa (Rutaceae) & Fruit & Available & Available & $2-5$ per fruit \\
\hline Alocasia macrorrhiza Schott (Araceae) & Corm, stem & Available & Available & $\begin{array}{l}\text { Corm } 10-20 \text { per kg } \\
\text { Stem } 10-15 \text { per kg }\end{array}$ \\
\hline Alpinia nigra (Gaertn.) Butt (Zingiberaceae) & Stem & Available & NA & 10-15 per kg \\
\hline Amaranthus spinosus L. (Amaranthaceae) & Tender shoot & Available & Available & 5-10 per bundle (200-300 g) \\
\hline Artocarpus heterophyllus Lam. (Moraceae) & Fruits & Available & NA & 10 per kg \\
\hline Averrhoa carambola L. (Oxalidaceae) & Fruit & Available & NA & 10-15 per kg \\
\hline Baccaurea ramiflora Lour. (Phyllanthaceae) & Fruit & Available & Available & 20-30 per kg \\
\hline Boesenbergia rotunda (L.) Mansf. (Zingiberaceae) & Rhizome & Available & NA & 15-20 per kg \\
\hline Choerospondias axillaris (Roxb.) B.L.Burtt \& A.W.Hill (Anacardiaceae) & Fruit & Available & NA & 15 per kg \\
\hline Citrus assamensis R.M.Dutta \& Bhattacharya (Rutaceae) & Fruit & Available & Available & $2-4$ per fruit \\
\hline Colocasia esculenta (L.) Schott (Araceae) & Tuber & Available & NA & 10 per kg \\
\hline Dendracalamus hamiltonii Nees et Arn. ex Munro (Poaceae) & Shoots & Available & NA & 15 per kg \\
\hline Dillenia indica L. (Dilleniaceae) & Fruit & Available & NA & 20 per $\mathrm{kg}$ \\
\hline Dioscorea alata L. (Dioscoreaceae) & Tuber & Available & NA & 10 per kg \\
\hline Gnetum gnemon L. (Gnetaceae) & Leaves & Available & NA & 10 per bundle (150-200 g) \\
\hline Hibiscus sabdariffa L. (Malvaceae) & Fruit & Available & NA & 10 per bundle $(450-500 \mathrm{~g})$ \\
\hline Musa paradisiaca L. (Musaceae) & Fruit, inflorescence & Available & NA & $\begin{array}{l}5 \text { per bundle } \\
10 \text { per inflorescence }\end{array}$ \\
\hline Musa balbisiana Colla (Musaceae) & Fruit, inflorescence & Available & NA & $\begin{array}{l}5 \text { per bundle } \\
10 \text { per inflorescence }\end{array}$ \\
\hline Parkia timoriana (DC.) Merr. (Fabaceae) & Fruit & Available & NA & 30 per kg \\
\hline Phlogacanthus thyrsiflorus Nees (Acanthaceae) & Inflorescence & Available & Available & 10 per bundle (150-200 g) \\
\hline Phyllanthus acidus (L.) Skeels (Phyllanthaceae) & Fruit & Available & NA & 10-20per kg \\
\hline Phyllanthus emblica L. (Phyllanthaceae) & Fruit & Available & Available & 10-20 per kg \\
\hline Piper nigrum L. (Piperaceae) & Fresh seed & Available & NA & 150-200 per kg \\
\hline Piper thomsonii (C. DC.) Hook. f. (Piperaceae) & Fresh seed & Available & NA & 40-50 per kg \\
\hline Rhynchotechum ellipticum (Wall, ex Dietr.) A. DC. (Gesneriaceae) & Tender leaf & Available & NA & 10 per bundle (150-200 g) \\
\hline Sesamum abbreviatum Merxm. (Pedaliaceae) & Dry seed & Available & NA & 80 per kg \\
\hline Syzygium cumini (L.) Skeels, (Myrtaceae) & Fruit & Available & Available & 20-25 per kg \\
\hline Terminalia arjuna Wight and Arn. (Combretaceae) & Bark & NA & Available & 15-20 per bundle (500-600 g) \\
\hline Zanthoxylum rhetsa (Roxb.) DC (Rutaceae) & Tender shoot & Available & NA & 10-15 per bundle (250-300 g) \\
\hline Zingiber chrysanthum Rosc. (Zingiberaceae) & Fruit & Available & Available & 25-30 per kg \\
\hline Zingiber officinale Rosc. (Zingiberaceae) & Rhizome & Available & Available & 20-25 per kg \\
\hline Zingiber rubens Roxb. (Zingiberaceae) & Shoot & Available & NA & 15-20 per kg \\
\hline Zingiber zerumbet (L.) Rose, ex Seem. (Zingiberaceae) & Inflorescence & Available & NA & 10-15 per bundle (350-400 g) \\
\hline Zizyphus xylopyrus (Retz) Willd. (Rhamnaceae) & Fruit & Available & NA & 15-20 per kg \\
\hline
\end{tabular}

$N A$ the item is not available in the local market as food or as medicine

$20 \%$ of the entire interviewed households raised less than $20 \%$ of their incomes from NTFP-based enterprises in the study, this shows that NTFPs constitute an essential component of the rural household economy in the study area.

\section{Non-timber forest product collection based on gender typology}

The gender typology for NTFPs collection in East Karbi Anglong Wildlife Sanctuary revealed that both men and women were involved in the collection of NTFPs. 
Table 11 List of NTFPs with different categories of uses and their use value

\begin{tabular}{|c|c|c|c|c|c|c|}
\hline Botanical name (voucher no.) & $\begin{array}{l}\text { Medicinal } \\
\text { uses }\end{array}$ & $\begin{array}{l}\text { Wild edible } \\
\text { uses }\end{array}$ & $\begin{array}{l}\text { Household building materials } \\
\text { and utensil }\end{array}$ & $\begin{array}{l}\text { Spices and condiment } \\
\text { uses }\end{array}$ & $\begin{array}{l}\text { Dye } \\
\text { uses }\end{array}$ & $\begin{array}{l}\text { Use value }(U V= \\
U / n)\end{array}$ \\
\hline Abroma augustum (EKAWLS141) & + & - & - & - & - & 0.028 \\
\hline Abrus precatorius (EKAWLS160) & + & - & + & - & - & 0.057 \\
\hline Acacia pennata (EKAWLS179) & + & - & - & - & - & 0.071 \\
\hline Aegle marmelos (EKAWLS200) & + & + & - & - & - & 0.085 \\
\hline Alocasia macrorrhiza (EKAWLS221) & + & + & - & - & - & 0.057 \\
\hline Alpinia nigra (EKAWLS199) & + & + & - & - & - & 0.071 \\
\hline Alternanthera sessilis (EKAWLS222) & + & - & - & - & - & 0.042 \\
\hline $\begin{array}{l}\text { Alternanthera philoxeroides } \\
\text { (EKAWLS240) }\end{array}$ & + & - & - & - & - & 0.028 \\
\hline $\begin{array}{l}\text { Amaranthus spinosus } \\
\text { (EKAWLS142) }\end{array}$ & + & + & - & - & - & 0.042 \\
\hline $\begin{array}{l}\text { Amblovenatum } \\
\text { opulentum(EKAWLS251) }\end{array}$ & + & - & - & - & - & 0.014 \\
\hline $\begin{array}{l}\text { Amorphophallus bulbifer } \\
\text { (EKAWLS260) }\end{array}$ & - & + & - & - & - & 0.014 \\
\hline Annona reticulate (EKAWLS159) & + & + & - & - & - & 0.057 \\
\hline Annona squamosa (EKAWLS178) & + & - & - & - & - & 0.014 \\
\hline Aralia armata (EKAWLS239) & - & & - & - & - & 0.014 \\
\hline Areca catechu (EKAWLS161) & - & - & + & - & - & 0.014 \\
\hline Artocarpus chama (EKAWLS252) & - & + & + & - & - & 0.042 \\
\hline $\begin{array}{l}\text { Artocarpus heterophyllus } \\
\text { (EKAWLS259) }\end{array}$ & - & + & - & - & - & 0.028 \\
\hline Artocarpus lacucha (EKAWLS220) & - & + & - & - & - & 0.028 \\
\hline Averrhoa carambola (EKAWLS162) & - & + & - & - & - & 0.014 \\
\hline Azadirachta indica (EKAWLS180) & + & - & - & - & - & 0.057 \\
\hline Baccaurea ramiflora (EKAWLS198) & + & + & - & - & - & 0.042 \\
\hline Bambusa afjinis (EKAWLS238) & - & - & + & - & - & 0.014 \\
\hline Bambusa pallida (EKAWLS158) & - & - & + & - & - & 0.014 \\
\hline Bambusa tulda (EKAWLS201) & - & - & + & - & - & 0.014 \\
\hline Bauhinia racemosa (EKAWLS224) & + & - & - & - & - & 0.042 \\
\hline Bauhinia variegata (EKAWLS241) & + & - & + & - & - & 0.128 \\
\hline $\begin{array}{l}\text { Boesenbergia rotunda } \\
\text { (EKAWLS177) }\end{array}$ & - & - & - & - & - & 0.014 \\
\hline Bridelia retusa (EKAWLS143) & + & - & - & - & - & 0.071 \\
\hline Bridelia tomentosa (EKAWLS181) & + & - & - & - & - & 0.014 \\
\hline Calamus erectus (EKAWLS197) & - & + & + & - & - & 0.028 \\
\hline Callicarpa arborea (EKAWLS202) & - & - & + & - & - & 0.014 \\
\hline Capsicum annuum (EKAWLS237) & + & - & - & - & - & 0.057 \\
\hline Careya arborea (EKAWLS157) & + & - & + & - & - & 0.028 \\
\hline Cassia fistula (EKAWLS242) & - & - & + & - & - & 0.014 \\
\hline Castanopsis indica (EKAWLS252) & - & + & + & - & - & 0.028 \\
\hline Centella asiatica (EKAWLS163) & + & - & - & - & - & 0.128 \\
\hline $\begin{array}{l}\text { Cheilocostus speciosus } \\
\text { (EKAWLS293) }\end{array}$ & + & - & - & - & - & 0.042 \\
\hline $\begin{array}{l}\text { Choerospondias axillaris } \\
\text { (EKAWLS286) }\end{array}$ & - & + & - & - & - & 0.014 \\
\hline
\end{tabular}


Table 11 List of NTFPs with different categories of uses and their use value (Continued)

\begin{tabular}{|c|c|c|c|c|c|c|}
\hline Botanical name (voucher no.) & $\begin{array}{l}\text { Medicinal } \\
\text { uses }\end{array}$ & $\begin{array}{l}\text { Wild edible } \\
\text { uses }\end{array}$ & $\begin{array}{l}\text { Household building materials } \\
\text { and utensil }\end{array}$ & $\begin{array}{l}\text { Spices and condiment } \\
\text { uses }\end{array}$ & $\begin{array}{l}\text { Dye } \\
\text { uses }\end{array}$ & $\begin{array}{l}\text { Use value }(U V= \\
U / n)\end{array}$ \\
\hline Cissampelos pareira (EKAWLS225) & + & - & - & - & - & 0.114 \\
\hline Citrus assamensis (EKAWLS176) & + & - & - & - & - & 0.042 \\
\hline $\begin{array}{l}\text { Clerodendrum infortunatum } \\
\text { (EKAWLS288) }\end{array}$ & + & - & - & - & - & 0.042 \\
\hline $\begin{array}{l}\text { Clinopodium umbrosum } \\
\text { (EKAWLS219) }\end{array}$ & - & - & - & - & - & 0.014 \\
\hline Coix lacryma-jobi (EKAWLS144) & - & + & - & - & - & 0.014 \\
\hline Colocasia esculenta (EKAWLS183) & - & + & - & - & - & 0.014 \\
\hline Croton caudatus (EKAWLS196) & - & - & - & - & + & 0.014 \\
\hline Cucumis melo (EKAWLS236) & - & + & - & - & - & 0.014 \\
\hline Curcuma longa (EKAWLS243) & + & - & - & - & + & 0.114 \\
\hline Dalbergia sisso (EKAWLS253) & - & - & + & - & - & 0.114 \\
\hline Datura metel (EKAWLS287) & + & - & - & - & - & 0.042 \\
\hline $\begin{array}{l}\text { Dendracalamus hamiltonii } \\
\text { (EKAWLS278) }\end{array}$ & - & + & + & + & - & 0.042 \\
\hline $\begin{array}{l}\text { Dendrocalamus strictus } \\
\text { (EKAWLS203) }\end{array}$ & + & - & - & - & - & 0.028 \\
\hline Dillenia indica (EKAWLS175) & - & + & - & - & - & 0.014 \\
\hline Dillenia pentagyna (EKAWLS156) & - & + & - & - & - & 0.014 \\
\hline Dioscorea alata (EKAWLS275) & - & + & - & - & - & 0.014 \\
\hline Dipteris wallichii (EKAWLS218) & - & - & + & - & - & 0.014 \\
\hline Drymaria cordata (EKAWLS226) & + & - & - & - & - & 0.100 \\
\hline Ehretia acuminata (EKAWLS254) & - & - & - & - & + & 0.028 \\
\hline Engelhardtia spicata (EKAWLS184) & - & + & - & - & - & 0.014 \\
\hline Ficus benghalensis (EKAWLS244) & + & - & - & - & - & 0.042 \\
\hline Ficus hispida (EKAWLS164) & + & - & - & - & - & 0.071 \\
\hline Ficus racemosa (EKAWLS274) & + & - & - & - & - & 0.042 \\
\hline $\begin{array}{l}\text { Garcinia pedunculata } \\
\text { (EKAWLS255) }\end{array}$ & - & + & - & - & - & 0.014 \\
\hline $\begin{array}{l}\text { Garcinia xanthochymus } \\
\text { (EKAWLS258) }\end{array}$ & - & - & - & - & + & 0.014 \\
\hline Garuga pinnata (EKAWLS235) & - & - & + & - & - & 0.014 \\
\hline Geophila repens (EKAWLS196) & + & - & - & - & - & 0.042 \\
\hline Gnetum gnemon (EKAWLS272) & - & + & - & - & - & 0.028 \\
\hline Habenaria dentata (EKAWLS216) & + & - & - & - & - & 0.042 \\
\hline Hedyotis scandens (EKAWLS204) & + & - & - & - & - & 0.014 \\
\hline Hibiscus cannabinus (EKAWLS174) & + & - & - & - & - & 0.071 \\
\hline Hibiscus sabdariffa (EKAWLS145) & + & + & + & - & - & 0.085 \\
\hline $\begin{array}{l}\text { Hodgsonia macrocarpa } \\
\text { (EKAWLS185) }\end{array}$ & - & + & - & - & - & 0.014 \\
\hline $\begin{array}{l}\text { Hydrocotyle sibthorpioides } \\
\text { (EKAWLS245) }\end{array}$ & + & - & - & - & - & 0.042 \\
\hline $\begin{array}{l}\text { Ichnocarpus frutescens } \\
\text { (EKAWLS195) }\end{array}$ & + & - & - & - & - & 0.100 \\
\hline Indigofer tinctoria (EKAWLS155) & - & - & - & - & + & 0.028 \\
\hline Kaempferia galanga (EKAWLS205) & + & - & - & - & - & 0.014 \\
\hline Leea indica (EKAWLS226) & + & - & - & - & - & 0.042 \\
\hline
\end{tabular}


Table 11 List of NTFPs with different categories of uses and their use value (Continued)

\begin{tabular}{|c|c|c|c|c|c|c|}
\hline Botanical name (voucher no.) & $\begin{array}{l}\text { Medicinal } \\
\text { uses }\end{array}$ & $\begin{array}{l}\text { Wild edible } \\
\text { uses }\end{array}$ & $\begin{array}{l}\text { Household building materials } \\
\text { and utensil }\end{array}$ & $\begin{array}{l}\text { Spices and condiment } \\
\text { uses }\end{array}$ & $\begin{array}{l}\text { Dye } \\
\text { uses }\end{array}$ & $\begin{array}{l}\text { Use value }(U V= \\
U / n)\end{array}$ \\
\hline Leucas aspera (EKAWLS234) & + & - & - & - & - & 0.042 \\
\hline Lippia alba (EKAWLS261) & + & - & - & - & - & 0.042 \\
\hline Livistona jenkinsiana (EKAWLS165) & - & - & + & - & - & 0.014 \\
\hline Magnolia hodgsonii (EKAWLS217) & + & - & - & - & - & 0.071 \\
\hline Mangifera indica (EKAWLS271) & + & - & + & - & - & 0.057 \\
\hline $\begin{array}{l}\text { Melastoma nepalensis } \\
\text { (EKAWLS146) }\end{array}$ & - & + & - & - & - & 0.014 \\
\hline Mesua ferrea (EKAWLS154) & - & - & + & - & - & 0.014 \\
\hline Moringa oleifera (EKAWLS173) & + & - & - & - & - & 0.014 \\
\hline Murraya koenigii (EKAWLS186) & + & + & - & - & - & 0.085 \\
\hline Musa paradisiaca (EKAWLS194) & - & + & - & - & - & 0.028 \\
\hline Musa balbisiana (EKAWLS233) & - & + & - & - & - & 0.028 \\
\hline Mussaenda isertiana (EKAWLS262) & - & + & - & - & - & 0.014 \\
\hline $\begin{array}{l}\text { Nyctanthes arbor-tristis } \\
\text { (EKAWLS269) }\end{array}$ & + & - & - & - & - & 0.042 \\
\hline $\begin{array}{l}\text { Ocimum gratissimum } \\
\text { (EKAWLS206) }\end{array}$ & + & - & - & - & - & 0.028 \\
\hline Olax acuminata (EKAWLS227) & - & + & - & - & - & 0.014 \\
\hline Oreocnide integrifolia (EKAWLS257) & - & + & - & - & - & 0.014 \\
\hline Oroxylum indicum (EKAWLS216) & + & + & - & - & - & 0.128 \\
\hline Oxalis corniculata (EKAWLS246) & + & - & - & - & - & 0.085 \\
\hline Paederia foetida (EKAWLS250) & - & + & - & - & - & 0.014 \\
\hline Parkia timoriana (EKAWLS228) & - & + & - & - & - & 0.014 \\
\hline Passiflora foetida (EKAWLS153) & - & + & - & - & - & 0.014 \\
\hline $\begin{array}{l}\text { Phlogacanthus tubiflorus } \\
\text { (EKAWLS172) }\end{array}$ & + & - & - & - & - & 0.057 \\
\hline $\begin{array}{l}\text { Phlogacanthus curviflorus } \\
\text { (EKAWLS268) }\end{array}$ & - & + & - & - & - & 0.014 \\
\hline $\begin{array}{l}\text { Phlogacanthus thyrsiflorus } \\
\text { (EKAWLS232) }\end{array}$ & - & + & - & - & - & 0.014 \\
\hline Phrynium pubinerve (EKAWLS166) & - & - & + & - & - & 0.014 \\
\hline Phyllanthus acidus (EKAWLS193) & - & + & - & - & - & 0.014 \\
\hline Phyllanthus emblica (EKAWLS187) & + & + & - & - & - & 0.014 \\
\hline Physalis peruviana (EKAWLS215) & + & + & - & - & - & 0.042 \\
\hline Piper nigrum (EKAWLS247) & - & - & - & - & - & 0.014 \\
\hline Piper thomsonii (EKAWLS147) & - & + & - & - & - & 0.028 \\
\hline $\begin{array}{l}\text { Polygonum microcephalum } \\
\text { (EKAWLS263) }\end{array}$ & - & + & - & - & - & 0.014 \\
\hline $\begin{array}{l}\text { Pseudocaryopteris foetida } \\
\text { (EKAWLS292) }\end{array}$ & + & - & - & - & - & 0.014 \\
\hline $\begin{array}{l}\text { Rhynchotechum ellipticum } \\
\text { (EKAWLS208) }\end{array}$ & - & + & - & - & - & 0.014 \\
\hline $\begin{array}{l}\text { Sarcochlamys pulcherrima } \\
\text { (EKAWLS249) }\end{array}$ & + & - & - & - & - & 0.042 \\
\hline $\begin{array}{l}\text { Sauropus androgynus } \\
\text { (EKAWLS231) }\end{array}$ & - & + & - & - & - & 0.014 \\
\hline Senna alexandrina (EKAWLS264) & + & - & - & - & - & 0.071 \\
\hline
\end{tabular}


Table 11 List of NTFPs with different categories of uses and their use value (Continued)

\begin{tabular}{|c|c|c|c|c|c|c|}
\hline Botanical name (voucher no.) & $\begin{array}{l}\text { Medicinal } \\
\text { uses }\end{array}$ & $\begin{array}{l}\text { Wild edible } \\
\text { uses }\end{array}$ & $\begin{array}{l}\text { Household building materials } \\
\text { and utensil }\end{array}$ & $\begin{array}{l}\text { Spices and condiment } \\
\text { uses }\end{array}$ & $\begin{array}{l}\text { Dye } \\
\text { uses }\end{array}$ & $\begin{array}{l}\text { Use value }(U V= \\
U / n)\end{array}$ \\
\hline $\begin{array}{l}\text { Sesamum abbreviatum } \\
\text { (EKAWLS192) }\end{array}$ & - & + & - & - & - & 0.042 \\
\hline Sida acuta (EKAWLS214) & + & - & - & - & - & 0.085 \\
\hline Sida rhombifolia (EKAWLS148) & + & - & - & - & - & 0.042 \\
\hline Solanum indicum (EKAWLS188) & + & + & - & - & - & 0.057 \\
\hline Solanum torvum (EKAWLS167) & + & - & - & - & - & 0.057 \\
\hline Stemona tuberosa (EKAWLS171) & + & - & - & - & - & 0.014 \\
\hline Sterculia villosa (EKAWLS152) & - & + & + & - & - & 0.028 \\
\hline Streblus asper (EKAWLS209) & - & + & - & - & - & 0.014 \\
\hline Strobilanthes cusia (EKAWLS213) & - & - & - & - & + & 0.014 \\
\hline Syzygium cumini (EKAWLS149) & + & + & - & - & - & 0.057 \\
\hline $\begin{array}{l}\text { Tabernaemontana divaricata } \\
\text { (EKAWLS170) }\end{array}$ & + & - & - & - & - & 0.057 \\
\hline Tephrosia purpurea (EKAWLS190) & + & - & - & - & - & 0.028 \\
\hline Terminalia arjuna (EKAWLS212) & + & - & - & - & - & 0.028 \\
\hline Terminalia bellirica (EKAWLS151) & + & - & - & - & + & 0.042 \\
\hline $\begin{array}{l}\text { Terminalia myriocarpa } \\
\text { (EKAWLS191) }\end{array}$ & - & - & + & - & - & 0.014 \\
\hline Tragia involucrata (EKAWLS168) & + & - & - & - & - & 0.014 \\
\hline Trema orientalis (EKAWLS210) & - & - & + & - & - & 0.014 \\
\hline Trevesia palmata (EKAWLS212) & - & + & - & - & - & 0.014 \\
\hline Wrightia coccinea (EKAWLS150) & - & - & + & - & - & 0.014 \\
\hline Zanthoxxlum rhetsa (EKAWLS229) & - & + & - & + & - & 0.057 \\
\hline $\begin{array}{l}\text { Zanthoxylum armatum } \\
\text { (EKAWLS248) }\end{array}$ & + & - & - & - & - & 0.014 \\
\hline $\begin{array}{l}\text { Zingiber chrysanthum } \\
\text { (EKAWLS256) }\end{array}$ & + & + & - & - & - & 0.114 \\
\hline Zingiber officinale (EKAWLS230) & + & - & - & + & - & 0.114 \\
\hline Zingiber rubens (EKAWLS211) & - & + & - & - & - & 0.014 \\
\hline Zingiber zerumbet (EKAWLS189) & - & + & - & - & - & 0.028 \\
\hline Zizyphus xylopyrus (EKAWLS169) & + & + & - & - & - & 0.071 \\
\hline
\end{tabular}

However, men were the most dominant extractors. Most of the collectors of edible forest products (90\%), ethnomedicines (80\%), household building materials and utensils (80\%), spices and condiments (50\%), and herbal dyes (40\%) were men, while most of the women were engaged in the collection of herbal dye (80\%), spices and condiments (70\%), ethnomedicines $(60 \%)$, edible forest products $(50 \%)$, and household building materials and utensils (40\%).

\section{Discussion}

The data generated from the respondents interviewed were from seven randomly selected rural and mountainous villages, covering the entire extent of the study area. The spatial variation in the area has therefore been adequately represented in our samples. The present study shows that NTFPs play a pivotal role in healthcare and livelihood security for the Karbi community. They are vital for maintaining the community at large for household uses, healthcare, and income generation as indicated by half the households arising $50-90 \%$ of their incomes of half from NTFPs collected from the sanctuary. Most of the revenue is generated by selling these products in the local markets in the form of wild vegetables and fruits. The stem of Alpinia nigra, shoot of Dendracalamus hamiltonii, fruit of Dillenia indica, tuber of Dioscorea alata, leaves of Gnetum gnemon, inflorescence of Phlogacanthus thyrsiflorus, seeds of Piper nigrum, etc. are commonly sold in the market. Other ways in which the NTFPs are used to generate incomes include selling as fibres, traditional wooden mortars, and weaving implements as well as various handicrafts (Fig. 4). The findings of the current study validate those of Timunpi 

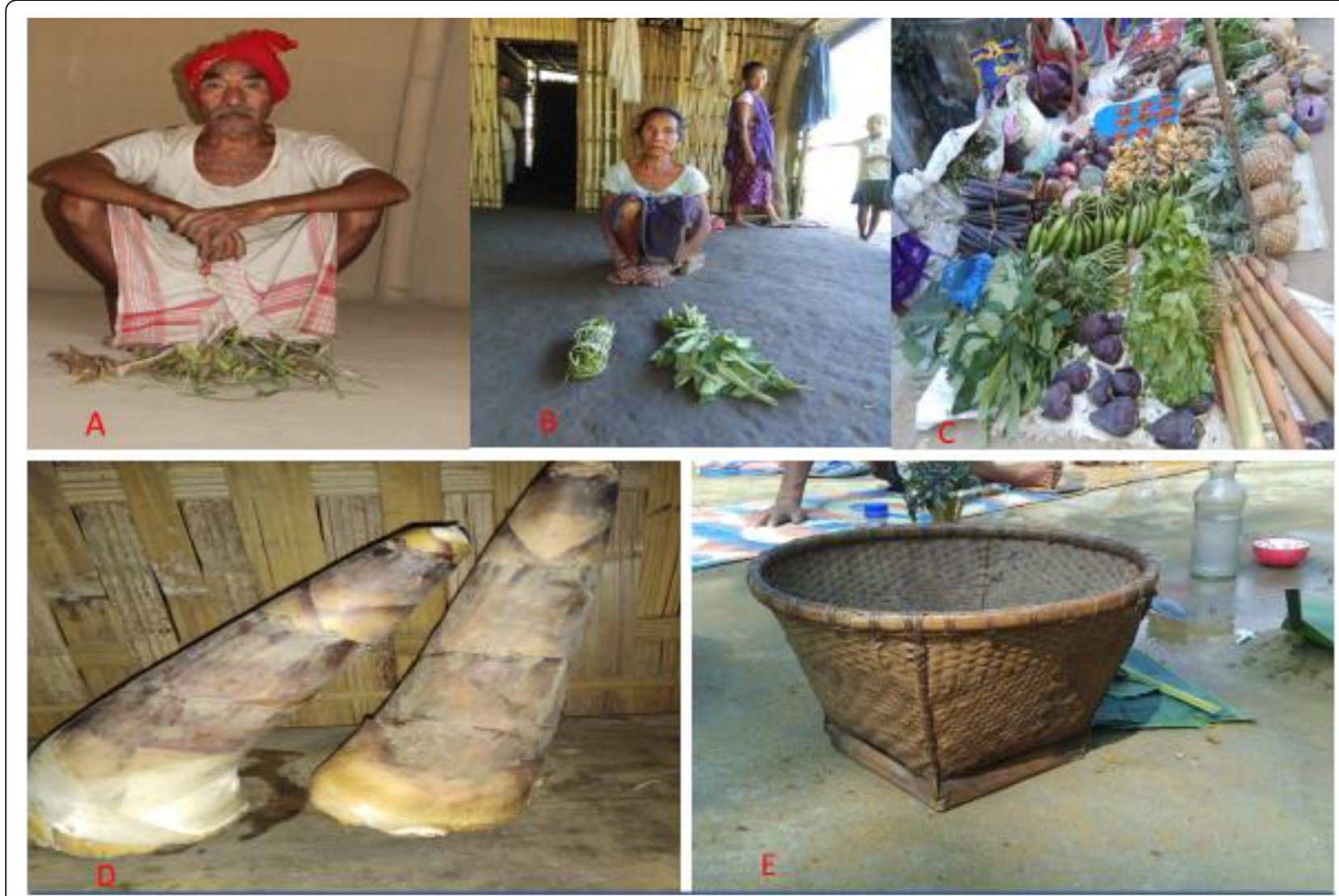

Fig. 4 a-b Informants. c Market with various forest products. $\mathbf{d}$ Bamboo shoots. e Basket made from bamboo and cane

(2017), who reported that forest is the backbone of the economy of the people living in this district.

The current study also highlights the diverse knowledge of ethnomedicinal plants exhibited by the Karbi community. Out of the 72 medicinal species recorded from the study area, the maximum number of species used as medicine was found in the family Fabaceae (6 species), followed by Malvaceae, Zingiberaceae, and Solanaceae (each with 5 species), while Rutaceae and Phyllanthaceae contribute 4 species each. Lamiaceae, Annonaceae, Moraceae, and Amaranthaceae each have 3 species, and Apiaceae, Apocynaceae, Verbenaceae, Rubiaceae, and Combretaceae have 2 species each while the remaining 18 families are monospecific. Plant species like Abroma augustum, Geophila repens, Habenaria dentata, Magnolia hodgsonii, Pseudocaryopteris foetida, Sarcochlamys pulcherrima, Stemona tuberosa, Tephrosia purpurea, Tragia involucrata, and Zingiber chrysanthum which have not been notified by earlier studies conducted elsewhere within the district among the Karbi tribe (Jain and Borthakur 1980; Teron and Borthakur 2012; Teron and Borthakur 2013; Terangpi et al. 2014; Teronpi et al. 2015) have been reported for their medicinal uses in this study. The present study along with the introduction of new medicinal plants also provides information of about the uses in treating 60 different types of ailments which include amenorrhea, dysmenorrhoea, dysentery, malaria, various skin infections, diarrhoea, bleeding gums cuts and wounds, helminthiasis, conjunctivitis, and constipation. This outcome supports the findings of Jain and Borthakur 1980 that ethnomedicines have always played a significant role in the healthcare system of the ethnic Karbis.

Data obtained using quantitative ethnobotanical studies have shown the significance of these plants among the Karbis. The plants (Centella asiatica, Cissampelos pareira, Dalbergia sisso, Ichnocarpus frutescens, etc.) with the highest UV are considered most important for the local people due to their multiple use reports and are therefore specifically conserved (Albuquerque et al. 2006). The ICF value for each of the 25 sub-categories ranged from 0.11 to 0.95 . While sub-categories like malaria, menstrual problems, and ectoparasitic controls showed higher ICF values of $\geq 0.91$, it is because only a few species for each category were used by the respondents. The plants associated with higher ICF value (Abroma augustum, Amaranthus spinosus, Geophila repens, Aegle marmelos, etc.) are used by a large portion 
of the community, implying that the communities at large have significant uses of these few plants for treating different ailments. Moreover, the variation in ICF value might be due to the availability and diversity of medicinal plants within the particular locality and restriction in exchange of ethnobotanical knowledge through generations (Hossain and Rahman 2018).

Most of the respondents used specific species for particular ailments as shown by the eight species having FL above $50 \%$. More work needs to be done on those particular plants which have high ICF and FL values to validate their uses as traditional medicines and to check their bioactive constituents for further drug development (Bibi et al. 2014). This type of study could open new paths for future pharmacological research, which can serve as a reference, especially for quantitative ethnobotanical investigations among diverse ethnolinguistic indigenous groups (Ong and Kim 2014). Research based on indigenous knowledge of various communities can yield a tremendous amount of cultural information which can potentially be utilised for economic and welfare benefits. Such information with proper scientific research could be beneficial in solving many modern-day problems, viz. food shortage, health issues, to curb famine, drought, and ways to manage and maintain sustainable utilisation of the natural wealth surrounding us. In recent decades, in many of the developing countries, there is an increasing demand for NTFPs for subsistence and cash income generation (Shackleton et al. 2011; Steele et al. 2015). Thus, NTFPs can play a significant role in commercial purposes which contribute to local economies and hence contribute to community development. In our study area, the NTFPs are mostly utilised for subsistence as well as for moderate cash income generation. However, inefficient utilisation of these resources due to insufficient knowledge could lead to overexploitation and depletion of these resources. These multiuse resources are being hampered by habitat destruction, overexploitation, unlimited grazing, change in land use pattern, and dominance of invasive species. Even so, the role of NTFPs in supporting livelihoods of rural communities is possible to continue as long as the resources are utilised sustainably (Solomon 2016).

\section{Conclusion}

Various ethnobotanical indices in the study have demonstrated and underscored the dependence of the forest dwellers on this living resource for their livelihood and subsistence. In addition to the use of the listed NTFPs, plants such as bamboo can support the local paper industries and other handicraft enterprises helping to augment their income. The informant consensus factors and fidelity level suggest that the ethnobotanical knowledge of the locals of this area is significantly diverse and useful. Inputs of these tribal experts should be given priority in bioassay and toxicity studies. From this study, we recommend Abroma augustum, Amaranthus spinosus, Geophila repens, Aegle marmelos, and Abrus precatorius for further ethnopharmacological studies, since these species have high ICF and FL values.

Moreover, UV data can be used to highlight those plants which need to be effectively conserved as they are resources which can sustain the indigenous population. Non-timber forest product management is a process involving harvesting, gathering, utilisation, and management of resources within the given ecological, economic, social, political, institutional, and legal frameworks. An effective NTFP policy is urgently required to link the provision of livelihood security as well as sustenance with biodiversity conservation. The high level of dependency on forest products by the different indigenous groups can affect the status of their forest. However, the efficient and eco-sensitive extraction of these forest products can not only add value to the forest product but also provide a proper incentive for conservation and sustainable forest management.

\section{Abbreviations \\ EKAWLS: East Karbi Anglong Wildlife Sanctuary; FL: Fidelity level; ICF: Informant consensus factor; NTFPs: Non-timber forest products; UR: Use report; UV: Use value}

\section{Acknowledgements}

The authors are thankful to the University Grant Commission (UGC), New Delhi, for the financial support through the National Fellowship for Higher Education of ST student. Authors are grateful to the Head, Centre for Advanced Studies in Botany, NEHU Shillong, for providing necessary facilities and Botanical Survey of India (Eastern Circle, Shillong) to consult the library and herbarium.

\section{Authors' contributions}

PM contributed to the collection of primary data from the study sites and to the analysis and interpretation of the data in the form of informant consensus factor and fidelity level. NAB contributed to the data calculation of all the plant species for all the four quantitative indices: (i) use report, (ii) use value, (iii) informant consensus factor, and (iv) fidelity level, and to the critical revision of the whole manuscript. DB contributed to the collection of primary data from the study sites and to the analysis and interpretation of all the data vitally. YK contributed to the design and drafting of the manuscript and to its critical revision. All authors read and approved the final manuscript.

\section{Funding}

University Grants Commission (UGC) in the form of National Fellowship for Higher Education (NFHE) of ST Students to pursue M.Phil./Ph.D. degree (F117.1/2016-17/NFST-2015-17-ST-ASS-2761).

\section{Availability of data and materials}

Data sharing is not applicable to this article as no datasets were generated or analysed during the current study.

Ethics approval and consent to participate Not applicable.

Consent for publication

Not applicable. 


\section{Competing interests}

The authors declare that they have no competing interests.

\section{Author details}

${ }^{1}$ Centre for Advanced Studies in Botany, North-Eastern Hill University, Shillong, Meghalaya 793022, India. ²Department of Botany, Rajiv Gandhi University, Doimukh, Arunachal Pradesh 791112, India.

\section{Received: 12 December 2018 Accepted: 20 September 2019} Published online: 25 October 2019

\section{References}

Agrawal A, Cashore B, Hardin R, Shepherd G, Benson C, Miller D (2013) Economic contributions of forest. Background paper prepared for the United Nations forum on forests. http://www.un.org/esa/forests/pdf/session_documents/ unff10/EcoContrForests.pdf , (Istanbul, 8-19 April). Accessed 8 Oct 2018

Albuquerque UP, Lucena RFP, Monteiro JM, Florentino ATN, Almeida CFCBR (2006) Evaluating two quantitative ethnobotanical techniques. Ethn Res Appl 4:51-60

Alexiades MN (1996) Selected guidelines for ethnobotanical research, a field manual. The New York Botanical Garden, New York, pp 99-133. https://doi. org/10.1080/14728028.2003.9752443

Alexiades MN, Sheldon JW (1996) Selected guidelines for ethnobotanical research: a field manual. New York Botanical Garden, New York

Amiguet VT, Arnason JT, Maquin P, Cal V, Vindas PS, Poveda L (2005) A consensus ethnobotany of the Q'eqchi' Maya of southern Belize. Econ Bot 59:29-42

Balakrishnan NP (1983) Flora of Jowai and vicinity, Meghalaya, 2 Vols. BSI, Howrah

Bibi T, Ahmad M, Tareen BR, Tareen MN, Jabeen R, Rehman US, Sultanaa S, Zafara M, Yaseena G (2014) Ethnobotany of medicinal plants in district Mastung of Balochistan province Pakistan. J Ethnopharmacol 157:79-89. https://doi.org/ 10.1016/j.jep.2014.08.042

Cocks ML, Wiersum KF (2003) The significance of plant diversity to rural households in the Eastern Cape province of South Africa. For. Trees Livelihoods 13:39-58

Cocksedge W (2006) Incorporating non-timber forest products into sustainable resource management: an overview for resource managers. Royal Roads University, Victoria

Dattagupta S, Gupta A (2016) Non-timber forest product (NTFP) in Northeast India: an overview of availability, utilization, and conservation. In: Bioprospecting of Indigenous Bioresources of North-East India. Springer, Singapore, pp 311-322

Dattagupta S, Gupta A, Ghose M (2010) Non-timber forest products of the inner line reserve Forest, Cachar, Assam, India. Assam University J Sci Tech: Biol Environ Sci 6(1):21-27

Dattagupta S, Gupta A, Ghose M (2014) Diversity of non-timber forest products in Cachar District, Assam. Ind J For Res 25(2):463-470

Endamana D, Angu KA, Akwah GN, Shepherd G, Ntumwel BC (2016) Contribution of non-timber forest products to cash and non-cash income of remote forest communities in Central Africa. Int For Rev 18(3):280-295

Haridasan K, Rao RR (1987) Forest Flora of Meghalaya. Vol. I-II. Bishen Singh and Mahendra Pal Singh, Dehradun

Höft M, Barik SK, Lykke AM (1999) Quantitative ethnobotany. Applications of multivariate and statistical analyses in ethnobotany. In: People and plants working paper 6. UNESCO, Paris, pp 1-49

Hossain U, Rahman OM (2018) Ethnobotanical uses and informant consensus factor of medicinal plants in Barisal District, Bangladesh. Bangladesh J Plant Taxon 25(2):241-255. https://doi.org/10.3329/bjpt.v25i2.39530

Hussain W, Badshah L, Ullah M, Ali M, Ali A, Hussain F (2018) Quantitative study of medicinal plants used by the communities residing in Koh-e-Safaid Range, northern Pakistani Afghan borders. J Ethnobiol Ethnomed 14:30. https://doi. org/10.1186/s13002-018-0229-4

Jain SK, Rao RR (1977) A handbook of field and herbarium methods. Today \& Tomorrow's Printers and Publishers, New Delhi, p 157

Kanjilal UN, Kanjilal PC, Das A, Purkayastha C (1939) Flora of Assam. Vol. I-IV. Government of Assam, Shillong

Kar A, Borthakur SK (2008) Wild vegetables of Karbi Anglong district. Assam Nat Prod Radiance 7(5):448-460

Kim H, Song MJ (2013) Ethnomedicinal practices for treating liver disorders of local communities in the southern regions of Korea. Evid Based Complement Alternat Med. https://doi.org/10.1155/2013/869176

Martin GJ (1995) Ethnobotany: a methods manual. Earthscan, London
Mishra M, Kotwal PC, Prasad C (2009) Harvesting of medicinal plants in the forest of Central India and its impact on quality of raw materials: a case of Nagpur District, India. Ecoprint 16:35-42

Ong GH, Kim DY (2014) Quantitative ethnobotanical study of the medicinal plants used by the Ati Negrito indigenous group in Guimaras island, Philippines. J Ethnopharmacol 157:228-242. https://doi.org/10.1016/j.jep.2014.09.015

Pandey RK, Saini SK (2007) Edible plants of tropical forests among tribal communities of Madhya Pradesh. Ind J Trad Knowledge 6(1):185-190

Phillips OLB, Gentry AH (1993) The useful plants of Tambopata, Peru. Il: additional hypothesis testing in quantitative ethno-botany. Econ Bot 47:32-43

Phongchopi U, Tamuli AK, Teron R (2014) Inventory of wild food plants in Marat Longri Wildlife Sanctuary in Assam, India. Pleione 8:331-343

Pieroni A (2001) Evaluation of the cultural significance of wild food botanicals traditionally consumed in Northwestern Tuscany, Italy. J Ethnobiol 21:89-104

Reyes-García V, Huanca T, Vadez V, Leonard W, Wilkie D (2006) Cultural, practical, and economic value of wild plants: a quantitative study in the Bolivian Amazon. Econ Bot 60:62-74

Ros-Tonen MAF, Dijkman W, Bueren ELV (1995) Commercial and sustainable extraction of non-timber forest products. In: Towards a policy and management oriented research strategy. The Tropenbos Foundation, Wageningen, p 32

Sankar S, Chowdhury S (2000) Survey of diversity of living economic flora and their conservation and development in the Karbi Anglong District of Assam. Envis Bulletin 8:1-4

Sarma J, Devi A, Sarma GC (2016) Exploration of non-timber forest products (NTFPs) used by the Mishing community in Sonitpur district of Assam, India. Pleione 10(1):23-31

Shaanker RU, Ganeshaiah KN, Krishnan S, Ramya R, Meera C, Aravind NA, Kumar A, Rao D, Vanaraj G, Ramachandra J, Gauthier R, Ghazoul J, Poole N, Reddy BVC (2004) Livelihood gain and ecological cost of non-timber forest product dependence: assessing the roles of dependence, ecological knowledge and market structure in three contrasting human and ecological settings in South India. Environ Conserv 31(3):242-253

Shackleton S, Delang CO, Angelsen A (2011) From subsistence to safety nets and cash income: exploring the diverse values of non-timber forest products for livelihoods and poverty alleviation, non-timber forest products in the global context. Springer, Berlin, pp 55-81

Singh AV (2017) Study on dye yielding plants of the Karbis of Nagaon, Assam. Int J Advan Res 5(7):382-385

Solomon MM (2016) Importance of non-timber forest production in sustainable forest management and its implication on carbon storage and biodiversity conservation in case of Ethiopia. J Biod Endangered Species 4:160. https:// doi.org/10.4172/2332-2543.1000160

Steele MZ, Shackleton CM, Shaanker RU, Ganeshaiah KN, Radloff S (2015) The influence of livelihood dependency, local ecological knowledge and market proximity on the ecological impacts of harvesting non-timber forest products. Forest Pol Econ 50:285-291

Terangpi R, Basumatary KT, Teron R (2014) Ethnomedicinal plants of the Karb ethnic group in Assam state (India) for management of gynaecological disorders. Int J Pharm Life Sci 5(10):3910-3916

Teron R, Borthakur SK (2012) Traditional knowledge of herbal dyes and cultural significance of colors among the Karbis ethnic tribe in Northeast India. Ethno Res Appl 10:594-604

Teron R, Borthakur SK (2013) Folklore claims of some medicinal plants as antidote against poisons among the Karbis of Assam. Pleione 7:346-356

Teronpi N, Terongpi R, Tamuli AK, Teron R (2015) Ethnobotanical investigations on antidotes in Singhason hills, Karbi Anglong district. Int J Res Ayurveda Pharma 6(1):150-156

Timunpi S (2017) A study on commercial uses of forest produces in Karbi Anglong district of Assam. Int J Acad Res Develop 2:173-176

Trotter RT, Logan MH (1986) Informant census: a new approach for identifying potentially effective medicinal plants. In: Etkin LN (ed) Plants in indigenous medicine and diet. Redgrave, Bedford Hill, New York, pp 91-112

Uddin ZM, Hassan MA (2014) Determination of informant consensus factor of ethnomedicinal plants used in Kalenga forest, Bangladesh. Bangla J plant Taxon 21(1):83-91

Upadhyay B, Singh KP, Kumar A (2011) Ethno-veterinary uses and informants consensus factor of medicinal plants of Sariska region, Rajasthan, India. J Ethnopharmacol 133:14-25

\section{Publisher's Note}

Springer Nature remains neutral with regard to jurisdictional claims in published maps and institutional affiliations. 